Article

\title{
Estimation of Mexico's Informal Economy and Remittances Using Nighttime Imagery
}

\author{
Tilottama Ghosh ${ }^{1,2, *}$, Sharolyn Anderson ${ }^{1}$, Rebecca L. Powell ${ }^{1}$, Paul C. Sutton ${ }^{1}$ and \\ Christopher D. Elvidge ${ }^{2}$
}

1 University of Denver, Department of Geography, 2050 E. Iliff Ave, Denver, Colorado 80208, USA; E-Mails: sander24@du.edu (S.A.); rpowell8@du.edu (R.L.P.); psutton@du.edu (P.C.S.)

2 Earth Observation Group, National Geophysical Data Center, National Oceanic and Atmospheric Administration, 325 Broadway, Boulder, Colorado 80305, USA; E-Mail: chris.elvidge@noaa.gov

* Author to whom correspondence should be addressed; E-Mails: tghosh@du.edu; tilottama.ghosh@noaa.gov; Tel.: +1-303-497-6385; Fax: +1-303-562-5950

Received: 15 May 2009; in revised form: 12 August 2009 / Accepted: 13 August 2009 / Published: 18 August 2009

\begin{abstract}
Accurate estimates of the magnitude and spatial distribution of both formal and informal economic activity have many useful applications. Developing alternative methods for making estimates of these economic activities may prove to be useful when other measures are of suspect accuracy or unavailable. This research explores the potential for estimating the formal and informal economy for Mexico using known relationships between the spatial patterns of nighttime satellite imagery and economic activity in the United States (U.S.). Regression models have been developed between spatial patterns of nighttime imagery and Adjusted Official Gross State Product (AGSP) for the U.S. states. These regression parameters derived from the regression models of the U.S. were 'blindly' applied to Mexico to estimate the Estimated Gross State Income (EGSI) at the sub-national level and the Estimated Gross Domestic Income (EGDI) at the national level. Comparison of the $E G D I$ estimate of Mexico against the official Gross National Income (GNI) estimate suggests that the magnitude of Mexico's informal economy and the inflow of remittances are 150 percent larger than their existing official estimates in the GNI.
\end{abstract}

Keywords: nighttime satellite imagery; informal economy; gross national income; gross domestic product; globalization; law of allometric growth 


\section{Introduction}

Measuring and understanding the spatial distribution of economic activity is a subject of considerable interest to social scientists. Globalization of the economy in the 1990s resulted in the 'informalization' of the workforce in many industries and countries [1]. Industrialization associated with globalization results in capital intensification, and, workers who lose their jobs resort to informal work. Decentralization of production increases the number of informal (i.e., unregistered) economic entities. In an attempt to cut the costs of production, many firms subcontract their services to these unregistered entities in countries that have lower labor costs because of these informal arrangements [2]. The new kind of capitalist development associated with globalization also results in the 'informalization' of employment relations even in the formal sector. In this arrangement, people are hired in non-standard jobs or atypical jobs with hourly wages and few benefits or into piece-rate jobs with no employment, social or work security. Households often supplement their incomes from the formal economy by working in the informal economy [3]. The decline in formal employment opportunities for the increasing population of urban areas is another major cause for the rise in informal employment [4]. Although there is no rigid boundary between formal and informal economic activities and they represent a continuum of economic relations, defining informal activity as a distinct sector is important in some developing countries where informal economic activity makes a significant contribution towards the economy.

A visible manifestation of informal economy is an increase in the number of street vendors in Mexico City, rickshaw pullers in Calcutta, barbers, cobblers, and vendors selling an increasingly diverse array of products including vegetables, fruit, dead fish, live chickens, cell phone batteries, and cigarettes. A less visible manifestation of this process are the informal workers who work in small shops or workshops (e.g., workshops that repair bicycles and motorcycles, tan leather and stitch shoes, make and embroider garments, sort and sell cloth, paper and metal waste). The least visible informal workers are mostly women who sell or produce goods from their homes, garment makers, paper bag makers, embroiderers, food processors, incense stick rollers, domestic laborers, and others [5]. This increased participation in the informal economy is associated with neoliberal policies such as the North American Free Trade Agreement (NAFTA).

Mexico was selected as the country of study in this paper because in the past quarter century Latin American countries have adopted these neoliberal doctrines (General Agreement on Tariffs and Trade, NAFTA, and World Trade Organization membership) almost universally, and this has had profound repercussions on the livelihoods of those who live and work in cities [6]. Policies associated with neoliberalism (e.g., privatization, deregulation, and trade liberalization) were expected to remove the obstacles to economic growth and result in job creation with respect to employment [7]. Nonetheless, these neoliberal reforms have had two primary consequences that many consider negative: 1) downsizing of the role of the state, 2) reduced employment in the traditional public sector, and 3) creation of more temporary, low wage and unprotected (i.e., informal) employment [8-10]. Thus, in the past two decades, men and women in cities throughout Latin America have increasingly taken up informal work as a livelihood strategy [10,11]. Informal economic activity, although a continuum of formal economic activity, has been recognized as a distinct economic sector throughout this paper because of its place of significance in the Mexican economy. 
Informed activists and researchers have worked with the International Labor Organization (ILO) to clarify the concept and definition of the 'informal sector' of the economy [12]. The research presented in this paper takes a very simple approach to this complex idea. We developed a model to estimate all economic activity using nighttime satellite imagery and ostensibly accurate Gross State Product (GSP) values for the U.S. states, inflated by 10 percent to account for the contribution of the informal economy (referred to as Adjusted Official Gross State Product, $A G S P_{U S_{i}}$ ), and applied them to Mexico. The value of the informal economy plus remittances for Mexico is simply the difference between the nighttime-satellite-image-based estimates and the official 'formal' measures of Gross National Income ( $\left.G N I_{M e x}\right)$ provided by the Instituto Nacional de Estadistica, Geografia e Informatica (INEGI, National Institute of Statistics and Geography).

The contribution of the informal economy towards the Gross Domestic Product (GDP) of a country, especially for developing countries, can be considerable. Compiling statistics on the size, composition and contribution of the informal economy is an extremely complicated exercise. The main difficulty is that very few countries have undertaken regular surveys of the informal sector, and only two or three countries have collected data that provide measures of informal employment outside informal enterprises. Also, there are a number of problems that hinder the international comparability of data as countries apply different criteria for non-registration, enterprise size, and/or workplace location. Most countries exclude agriculture from their measurement of the informal sector, and some measure only the urban informal sector [3].

Remittances contribute to the Gross National Income $(G N I)$ of a country, where GNI is the sum of Gross Domestic Product (GDP) plus net receipts of compensation of employees and property income from abroad. Remittances are the funds that the international migrants send back to their countries of origin. In recent years, remittances have emerged as a major source of external financing in developing countries. The quality and coverage of data on remittances is fraught with problems. In several countries, many types of formal remittance flows go unrecorded, due to weaknesses in data collection (related to both definitions and coverage) and flows through informal channels (such as unregulated money transfers or family and friends who carry cash). Remittances are frequently misclassified as export revenue, tourism receipts, nonresident deposits, or even foreign direct investment (FDI) [13].

Reliable measurements of the economic transactions of a nation expressed in terms of GNI and $G D P$ are difficult to obtain because of the lack of well developed national income accounting methods and the large size of the "informal" sector, especially in developing economies [14,15]. Official estimates of the GNI and GDP of countries can vary dramatically depending on the sources of data and the different accounting methods. A recent New York Times article demonstrated this when it noted that economists recognized a mistake in their measurement of the size of the Chinese economy as four trillion dollars more than what it really was. Their revised estimate of the size of the Chinese economy was six trillion dollars rather than ten trillion dollars, due to poor choices of purchasing power parity (PPP) parameters [16].

The problems of measuring the economic activities of a country in terms of GDP and GNI are further compounded when information is required on the spatial and temporal changes in economic activity [17]. However, estimates of the magnitude and distribution of the informal economy are important because, for countries where calculations have been made, it is seen that informal employment contributes about 25 percent of total GDP. Thus, the informal economy contributes to 
poverty alleviation and to the total economy by producing a significant share of total employment and $G D P$. Better estimates of informal employment would improve our understanding of the contribution of the informal economy to the total economy and its links to poverty. This would inform the development of appropriate policies and programs for those who work in the informal economy [5].

Remote sensing data provides an interesting alternative for measuring the values of these economic activities as such data provide a synoptic view of the terrestrial environment and are applied extensively to map the spatial distribution of population and to examine the impact of human presence on the environment [18]. For example, the Defense Meteorological Satellite Programs Operation Linescan System (DMSP-OLS) nighttime images, which have been archived in the National Oceanic and Atmospheric Administration, National Geophysical Data Center (NOAA, NGDC), since 1994, detects sources of nighttime lights, such as city lights, forest fires, gas flare burn-off, and lantern fishing, all produced by human activities [19]. Therefore, the DMSP-OLS can serve as a proxy measure of population and correlates of population such as economic activity and energy consumption [20]. Nighttime imagery has been used for myriad applications including estimation of urban populations [21-24], estimation of intra-urban population density [25,26], energy utilization or electric power consumption [21,22,24,27], delineating urban land cover [24,28], measuring anthropogenic impervious surface area [29], estimating GDP at the national and sub-national level [15,24,27,30,31], mapping marketed and non-marketed economic activity [32], estimation and mapping of $\mathrm{CO}_{2}$ emissions [30], mapping 'exurban' areas [33], mapping nocturnal squid fishing [34], and mapping fire and fire-prone areas [35].

Due to the problems associated with estimating the magnitude and spatial distribution of economic activity, we explore an alternative method. Building upon previous efforts, this paper explores the potential for estimating the values of these economic activities for Mexico using known relationships between the spatial patterns of nighttime satellite imagery and economic activity in the U.S. Using the arguably more reliable measures of GSP for the states of the U.S. and assuming the contribution of the informal economy towards GSP in the U.S. to be approximately 10 percent [36-39], we developed a model for estimating the Gross State Income $(G S I)$ of the 48 contiguous states of the U.S. The model was then used to estimate the GSI of Mexican states and the results were compared to the official GSP and GNI estimates, informal economy and remittances to estimate the contribution of the informal economy and remittances towards the GNI estimate of Mexico.

Since the official estimates of GSP, GDP, and GNI are believed to include most of the formal transactions in the economy, any excess of these economic values measured from the spatial patterns of nighttime lights can be attributed to informal economy and inflow of remittances, which often are underestimated in the official figures. When people are engaged in informal economic activities, especially in developing countries, the income earned improves their economic conditions and purchasing power. With the increase in purchasing power of the individuals, we assumed that individuals would make an effort to improve their standard of living and would acquire the basic amenities of modern day living, including electricity. Thus, the spread of electricity can be an indicator of economic development, and is manifested through a spread of electrification in cities, towns, and villages. The spread of electricity consumption, and consequently the level of economic development, can be estimated from the DMSP-OLS nighttime images. Thus, with the official measures accounting for the recorded formal activities, we assumed that the underestimated informal economy and flow of 
remittances into the economy can be estimated from the excess of economic activity measured from the nighttime lights.

\section{Data Sets}

\subsection{Radiance Calibrated Nighttime Satellite Imagery Data}

Proxy measure of economic activity for Mexico and the U.S. were based on the global radiancecalibrated "city lights of the world" data product. These data were derived from hundreds of orbits of the DMSP-OLS [40]. Different gain settings of the F12 and F15 satellites were used to make the radiance calibrated image of 2000-2001. The different gain settings were normalized to the 55 decibel (dB) gain setting of F15. The radiance value per digital number (DN) detected in the data acquired at the gain of $55 \mathrm{~dB}$ was $1.35 \times 10^{-10} \mathrm{watts} / \mathrm{cm}^{2} / \mathrm{sr}$, and the saturation radiance was $8.54 \times 10^{-9}$ watts $/ \mathrm{cm}^{2} / \mathrm{sr}$. The range of the radiance value of the image is 0 watts $/ \mathrm{cm}^{2} / \mathrm{sr}$ (either because there was no coverage or no data) to $6.73 \times 10^{-7}$ watts $/ \mathrm{cm}^{2} / \mathrm{sr}$ (4968 DNs). The data are referenced by latitude/longitude World Geodetic System (WGS 1984) coordinates. The radiance calibrated nighttime image was re-projected from geographic coordinates to the Mollweide Equal Area projection for extracting correct area information for all areas of the earth, from the equator to the poles (Figure 1). This was necessary as area estimates of the lit urban regions for the analysis were acquired from the DMSP-OLS image.

Figure 1. Radiance calibrated nighttime image of 2000-2001, Mexico in the inset.

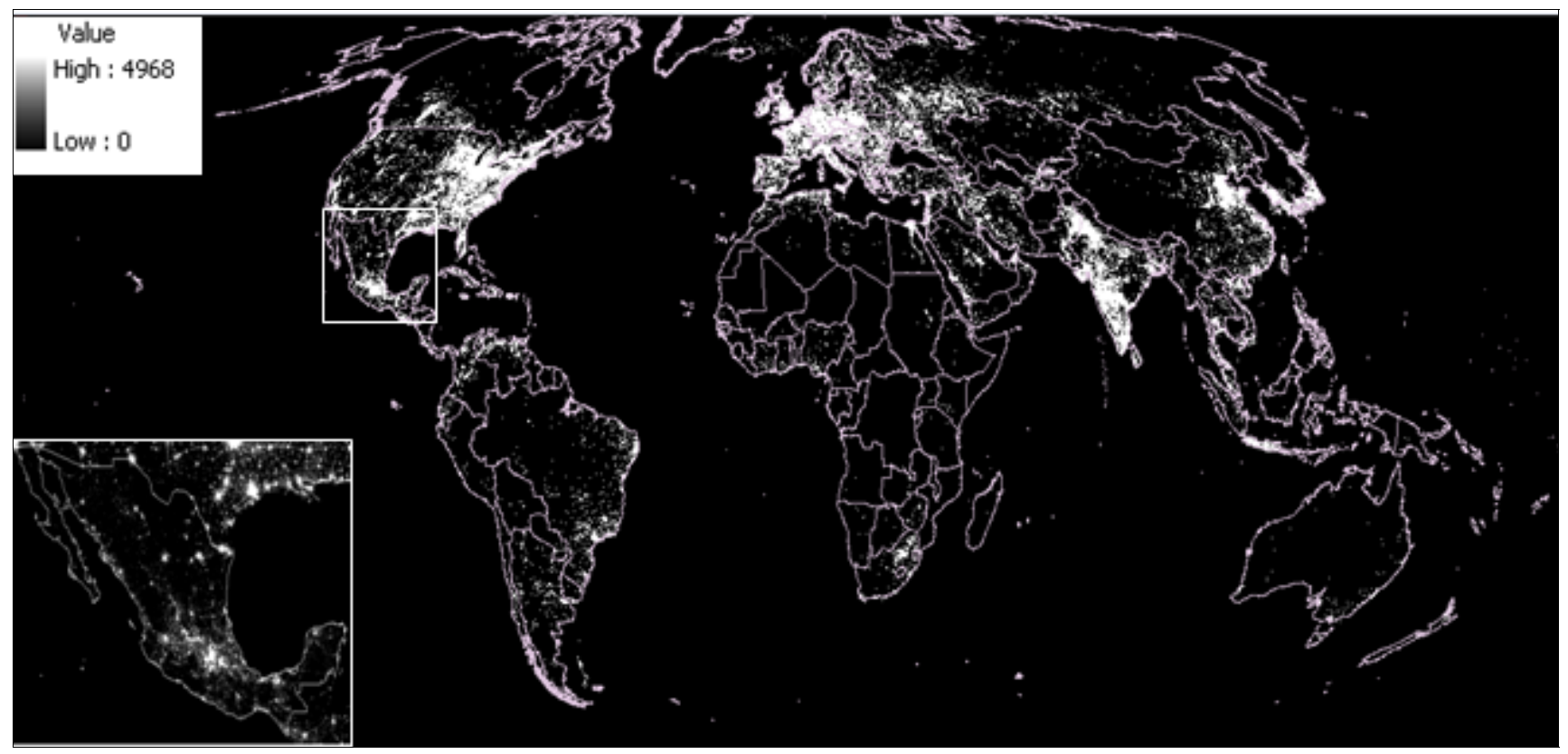

\subsection{Landscan Population Data}

The Landscan population dataset for the year 2000 was used to estimate population of the demarcated urban areas in this study. It comprises a world population database reporting population count per cell compiled on 30 arc-second grids. It was developed as part of the Oak Ridge National Laboratory (ORNL) Global Population Project for estimating ambient populations at risk. This dataset 
has been developed by apportioning census counts (at sub-national) level to each grid cell using likelihood coefficients based on proximity to roads, slope, land cover, and other information. The data are referenced by latitude/longitude (WGS 1984) coordinates (Figure 2) [41].

Figure 2. Landscan Population Data, 2000, Mexico in the inset.

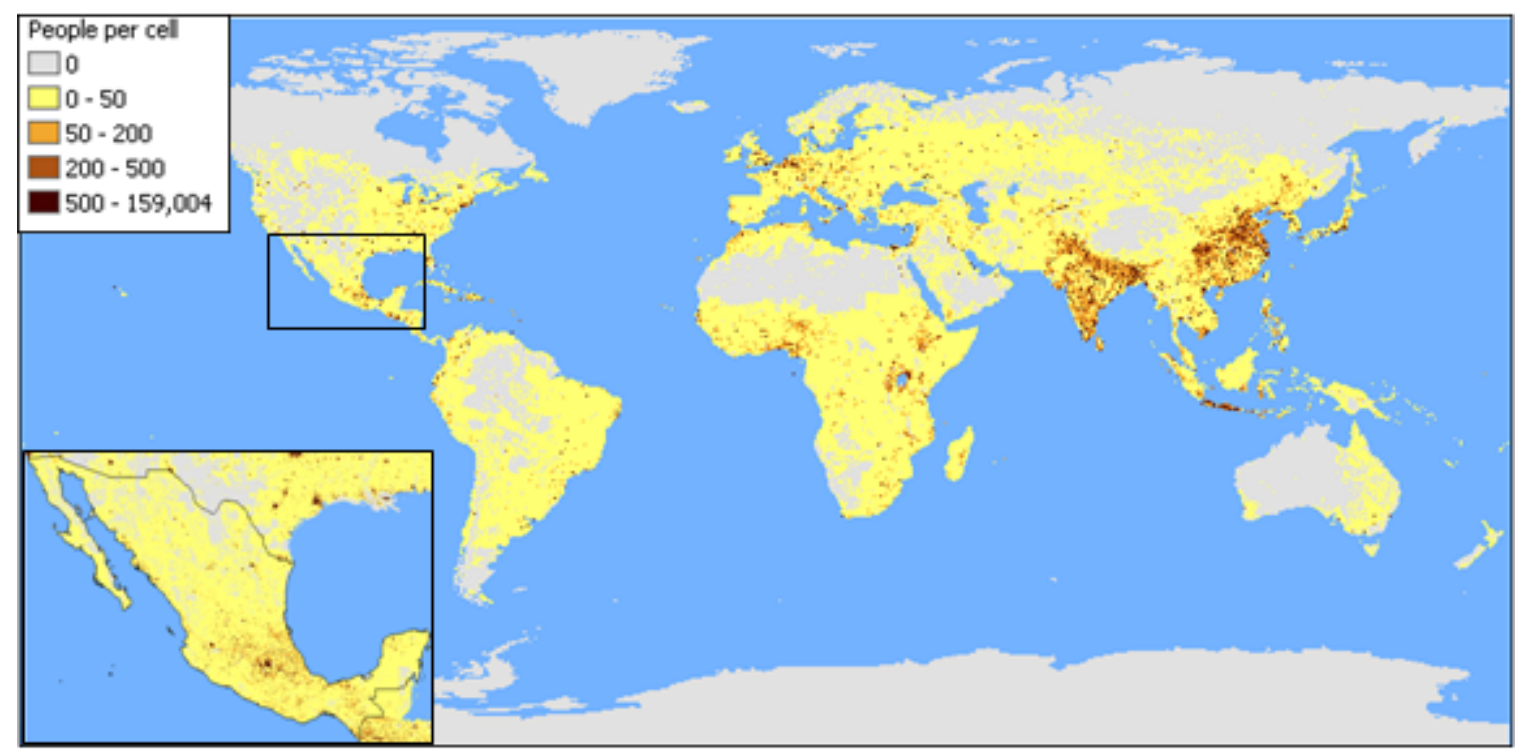

\subsection{Official Estimates of the GDP, GNI and GSP of the U.S. and Mexico}

Gross Domestic Product $(G D P)$ is the value of all final goods and services produced within the borders of a country's economy in a year, i.e., the aggregate economic activity within the country. $G D P$ at the state level is the Gross State Product $(G S P)$. In other words, GSP refers to economic activity in individual states of a country. Gross National Income $(G N I)$ is the sum of GDP plus net receipts of compensation of employees and property income from abroad. The inconsistencies between different GDP and GNI estimates for the U.S. and Mexico that are derived from different sources and/or through the application of different computing methods become conspicuous in Tables 1 and 2. For example, the U.S. GDP estimates range between U.S. $\$ 9,749$ billion and $\$ 9,883$ billion, while Mexico GDP estimates range between U.S. $\$ 521$ billion and Purchasing Power Parity (PPP) U.S. \$896 billion. This variation in the estimates underlines the importance of this study, which aims to develop an independent and standardized methodology to estimate the economic activities of a country.

GDP estimates for the U.S. for the year 2000 were obtained from the U.S. Bureau of Economic Analysis [42] and the World Development Report, 2002 [43]. The GNI estimate was obtained from the World Development Report, 2002 [43] and the second GNI estimate was calculated by multiplying the GNI per capita and Mid-2000 population data, available from the 2000 World Population Data Sheet [44].

For Mexico, the GDP estimate for the year 2000 in Pesos was obtained from INEGI [45]. In order to show the disparity in the values because of the use of different conversion methods, the GDP estimate was converted into U.S. dollars on the basis of the official exchange rate for 2000, as well as the PPP conversion factor (i.e., local currency units to international dollar) for 2000. PPP is defined as the number of units of a country's currency required to buy the same amount of goods and services in 
the domestic market as one dollar would buy in the U.S. [46]. Several sources of GNI estimates were obtained, including INEGI [47], the World Development Report, 2002 [43], and the World Population Data Sheet by multiplying the GNI per capita with the mid-2000 population [44]. The GNI estimates derived from INEGI and the World Development Report were also converted on the basis of the official exchange rate and PPP conversion factor for 2000.

The GSP for each U.S. state was obtained from the U.S. Bureau of Economic Analysis [42]. The GSP of the U.S. states do not include the contribution of the informal economy [48], and thus were adjusted by adding 10 percent of GSP to the GSP of each state, a statistic we refer to as the Adjusted Official Gross State Product $\left(A G S P_{U S_{i}}\right.$ ) (Table 5, Column 2). For Mexico, the GSP of each state for the year 2000 was obtained from INEGI. These are the Producto interno bruto por entidad federative, Total de la actividad económica (Gross internal product by Federal Organization, Total of the economic activity) [45]. The GSP estimates were converted into PPP U.S. dollars by applying the PPP conversion factor (PPP U.S. $\$ G S P_{\text {Mex }_{i}}$ ) (Table 6, Column 2).

In spite of these discrepancies in reported economic indicators, the adjusted GSP estimates $\left(A G S P_{U S_{i}}\right)$ derived from the U.S. Bureau of Economic Analysis were assumed to be the most reliable official estimates of GSP for any nation in the world, as the U.S. has the financial and technological resources to conduct elaborate and extensive economic surveys, which developing countries often lack [49]. Our subsequent analysis was based on the $A G S P_{U S_{i}}$ (Table 5). Also, since the PPP values are the standard used for international comparisons, the PPP U.S.\$ GNI estimate of Mexico ( $G N I_{M e x}$, in bold in Row 3 of Table 2) and the PPP U.S. $\$ G S P_{M_{\text {ex }}}$ (Table 6) were used to facilitate comparison of results.

Table 1. Comparison of the GNI and GDP estimates of the United States from different sources.

\begin{tabular}{cccccc}
\hline Row no. & Estimate & Year & Source & $\begin{array}{c}\text { Conversion techniques and } \\
\text { Currency units }\end{array}$ & Value \\
\hline 1 & GNI & 2000 & $\begin{array}{c}\text { World Dev. Report } \\
2002\end{array}$ & $\begin{array}{c}\text { Atlas method- using } 3 \text { year } \\
\text { average exchange rate }\end{array}$ & $\$ 9,646$ billion \\
2 & GNI & 2000 & $\begin{array}{c}\text { Population Reference } \\
\text { Bureau }\end{array}$ & In US Dollars & $\$ 8,059$ billion \\
3 & GDP & 2000 & $\begin{array}{c}\text { World Dev. Report } \\
\text { 2002 }\end{array}$ & $\begin{array}{c}\text { Average official exchange rate } \\
\text { of that year }\end{array}$ & \$ 9,883 billion \\
4 & GDP & 2000 & $\begin{array}{c}\text { U.S. Bureau of } \\
\text { Economic Analysis }\end{array}$ & Current US\$ & $\$ 9,749$ billion \\
\hline
\end{tabular}

\subsection{Official Estimates of the Informal Economy and Remittances of Mexico}

Estimate of the contribution of the informal economy to total GDP for Mexico for the year 2000 was obtained from INEGI [50]. A state-wise breakdown of the data was not available and only the total contribution of the informal economy towards $G D P$ was acquired (Table 3). According to INEGI estimates, the contribution of the informal economy towards GDP of Mexico for the year 2000 was approximately 12 percent. 
Table 2. Comparison of the GNI and GDP estimates of Mexico from different sources.

\begin{tabular}{|c|c|c|c|c|c|}
\hline Row no. & Estimate & Year & Source & $\begin{array}{c}\text { Conversion techniques and } \\
\text { Currency units } \\
\end{array}$ & Value \\
\hline 1 & GNI & 2000 & INEGI & In Pesos & 5,491 billion \\
\hline 2 & GNI & 2000 & INEGI & $\begin{array}{c}\text { In terms of exchange rate U.S. } \\
\text { Dollars }\end{array}$ & $\$ 574$ billion * \\
\hline 3 & GNI & 2000 & INEGI & PPP U.S. Dollars & \$ 886 billion * \\
\hline 4 & GNI & 2000 & $\begin{array}{l}\text { World Dev. Report } \\
2002\end{array}$ & $\begin{array}{l}\text { Atlas Method - using three year } \\
\text { average exchange rate }\end{array}$ & $\$ 498$ billion \\
\hline 5 & GNI & 2000 & $\begin{array}{l}\text { World Dev. Report } \\
2002\end{array}$ & PPP U.S. Dollars & $\$ 864$ billion $\boldsymbol{\Delta}$ \\
\hline 6 & GNI & 2000 & $\begin{array}{c}\text { Population Reference } \\
\text { Bureau }\end{array}$ & In U.S. Dollars & $\$ 382$ billion \\
\hline 7 & GDP & 2000 & INEGI & In Pesos & 4,984 billion \\
\hline 8 & GDP & 2000 & INEGI & $\begin{array}{c}\text { In terms of exchange rate U.S. } \\
\text { Dollars }\end{array}$ & $\$ 521$ billion \\
\hline 9 & GDP & 2000 & INEGI & PPP U.S. Dollars & $\$ 804$ billion \\
\hline 10 & GDP & 2000 & $\begin{array}{l}\text { World Dev. Report } \\
\qquad 2002\end{array}$ & $\begin{array}{c}\text { Average official exchange rate } \\
\text { of that year }\end{array}$ & $\$ 575$ billion \\
\hline 11 & GDP & 2000 & $\begin{array}{l}\text { World Dev. Report } \\
2002\end{array}$ & PPP U.S. Dollars & $\$ 896$ billion $^{\#}$ \\
\hline
\end{tabular}

Notes: * Calculated from row 1 in Table $2 ;{ }^{\boldsymbol{\Delta}}$ Calculated from row 4 in Table $2 ;{ }^{\bullet}$ Calculated from row 7 in Table $2 ;{ }^{\#}$ Calculated from row 10 in Table 2

Table 3. Reported value of the Informal Economy estimate of Mexico.

\begin{tabular}{cc}
\hline & Informal Economy (2000) \\
\hline In Pesos & 616 billion \\
In PPP U.S. Dollars & 99 billion \\
\hline
\end{tabular}

Source: INEGI, Sistema de Cuentas Nacionales de México, Cuentas por Sectores Insititucionales, Cuenta Satelite del Subsector informal de los hogares, 1998-2003

The data on the total flow of remittances into Mexico for the year 2000 was obtained from Banco de Mexico [51]. The contribution of remittances towards GNI for Mexico for the year 2000 was estimated to be 0.8 percent, a total value of 6.6 billion dollars.

\section{Methods}

\subsection{Data Analysis - Overview}

A brightness threshold was selected to delineate the lit urban regions of the states of the U.S. on the DMSP-OLS nighttime image. Area and population of the lit urban regions were aggregated to the state level ( $A_{U S_{i}}$ and $P_{U S_{i}}$ in Table 4). A model was developed based on the law of allometric growth to estimate population of the lit urban regions demarcated by the brightness threshold (Stage 1 in Figure 3, $P_{U S_{i}}^{\prime}$ in Table 4). In the next step (Stage 2 in Figure 3), a multiple regression model was 
developed to estimate Gross State Income of the U.S. states $\left(E G S I_{U S_{i}}\right.$ in Table 4) on the basis of the (1) estimated urban population of each state (from Stage 1), (2) sum of light intensity value of all lights above zero for each state $\left(S_{U S_{i}}\right.$ in Table 4), and (3) adjusted GSP of each U.S. state $\left(A G S P_{U S_{i}}\right.$ in Table 4). Next (Stage 3 in Figure 3), the same threshold developed in Stage 1 was used to demarcate the urban areas of the Mexican states $\left(A_{M e x_{i}}\right.$ in Table 4). Urban area was determined, and the 'U.S. equivalent urban population' was estimated using the model developed for the U.S. in Stage 1 ( $P^{\prime}{ }^{\prime} x_{i}$ in Table 4). The multiple regression model developed for the U.S. in Stage 2 was used to estimate the Gross State Income for each Mexican state (Stage 4 in Figure 3, EGSI $I_{M x_{i}}$ in Table 4). EGSI $I_{M x_{i}}$ for each state was summed to get the Estimated Gross Domestic Income $\left(E G D I_{M e x}\right)$ for the whole of Mexico. The underestimation of the informal economy and remittances in the official GNI estimate $\left(G N I_{M e x}\right.$ in Table 4) was calculated by subtracting the $G N I_{M e x}$ from the $E G D I_{M e x}$ (Stage 5 in Figure 3, UIER in Table 4). Definitions and abbreviations for all the economic variables which were developed and used in different stages of the analysis are presented in Table 4.

Table 4. Abbreviations and definitions of the different economic variables used in the text.

\begin{tabular}{|c|c|}
\hline Abbreviations & Definitions \\
\hline$A_{U S_{i}}$ & $\begin{array}{l}\text { Area of the lit urban areas of each U.S. state }(i) \text {, demarcated by the brightness threshold of } 20 \\
\times 1.35 \times 10^{-10}\end{array}$ \\
\hline$P_{U S_{i}}$ & $\begin{array}{l}\text { Population (extracted from the Landscan dataset) of the lit urban areas, demarcated by the } \\
\text { brightness threshold, for each U.S. state }(i)\end{array}$ \\
\hline$P_{U S_{i}}^{\prime}$ & $\begin{array}{l}\text { Estimated urban population of the lit urban areas, demarcated by the brightness threshold, for } \\
\text { each U.S. state }(i)\end{array}$ \\
\hline$S_{U S_{i}}$ & 'Sum of lights' of the lit areas for each U.S. state (i) \\
\hline$A G S P_{U S_{i}}$ & $\begin{array}{l}\text { Adjusted Official Gross State Product for each U.S. state }(i) \text { : official GSP is inflated by } 10 \% \\
\text { to account for the contribution of the informal economy }\end{array}$ \\
\hline$E G S I_{U S_{i}}$ & $\begin{array}{l}\text { Estimated Gross State Income for each U.S. state }(i) \text { : sum of the formal economy, informal } \\
\text { economy and remittances as estimated from the nighttime lights image }\end{array}$ \\
\hline Residual $_{U S i}$ & $\begin{array}{l}\text { Residual Percentage for each U.S. state }(i) \text {, percentage difference between official } A G S P_{U S} \\
\text { and modeled } E G S I_{U S}\end{array}$ \\
\hline$A_{\text {Mex }_{i}}$ & $\begin{array}{l}\text { Area of the lit urban areas for each Mexican state }(i) \text {, demarcated by the brightness threshold } \\
\text { of } 20 \times 1.35 \times 10^{-10}\end{array}$ \\
\hline$P^{\prime}$ Mex $_{i}$ & $\begin{array}{l}\text { Estimated 'U.S. equivalent urban population' of the lit urban areas, demarcated by the } \\
\text { brightness threshold, for each Mexican state (i) }\end{array}$ \\
\hline$S_{M e x_{i}}$ & 'Sum of lights' of the lit areas for each Mexican state (i) \\
\hline$G S P_{\text {Mex }_{i}}$ & Official Gross State Product of each Mexican state (i) \\
\hline$E G S I_{\text {Mex }_{i}}$ & $\begin{array}{l}\text { Estimated Gross State Income for each Mexican state }(i) \text { : sum of the formal economy, } \\
\text { informal economy and remittances as estimated from the nighttime lights image }\end{array}$ \\
\hline$E G D I_{M e x}$ & Estimated Gross Domestic Income of Mexico (sum of EGSI for all states) \\
\hline$G N I_{M e x}$ & Official Gross National Income of Mexico \\
\hline UIER & $\begin{array}{l}\text { Predicted underestimation of informal economy and remittances in the official estimates of } \\
\text { GNI }\end{array}$ \\
\hline
\end{tabular}


Figure 3. Overview of the model to predict the underestimation of informal economy and remittances in Mexico's official GNI measure .

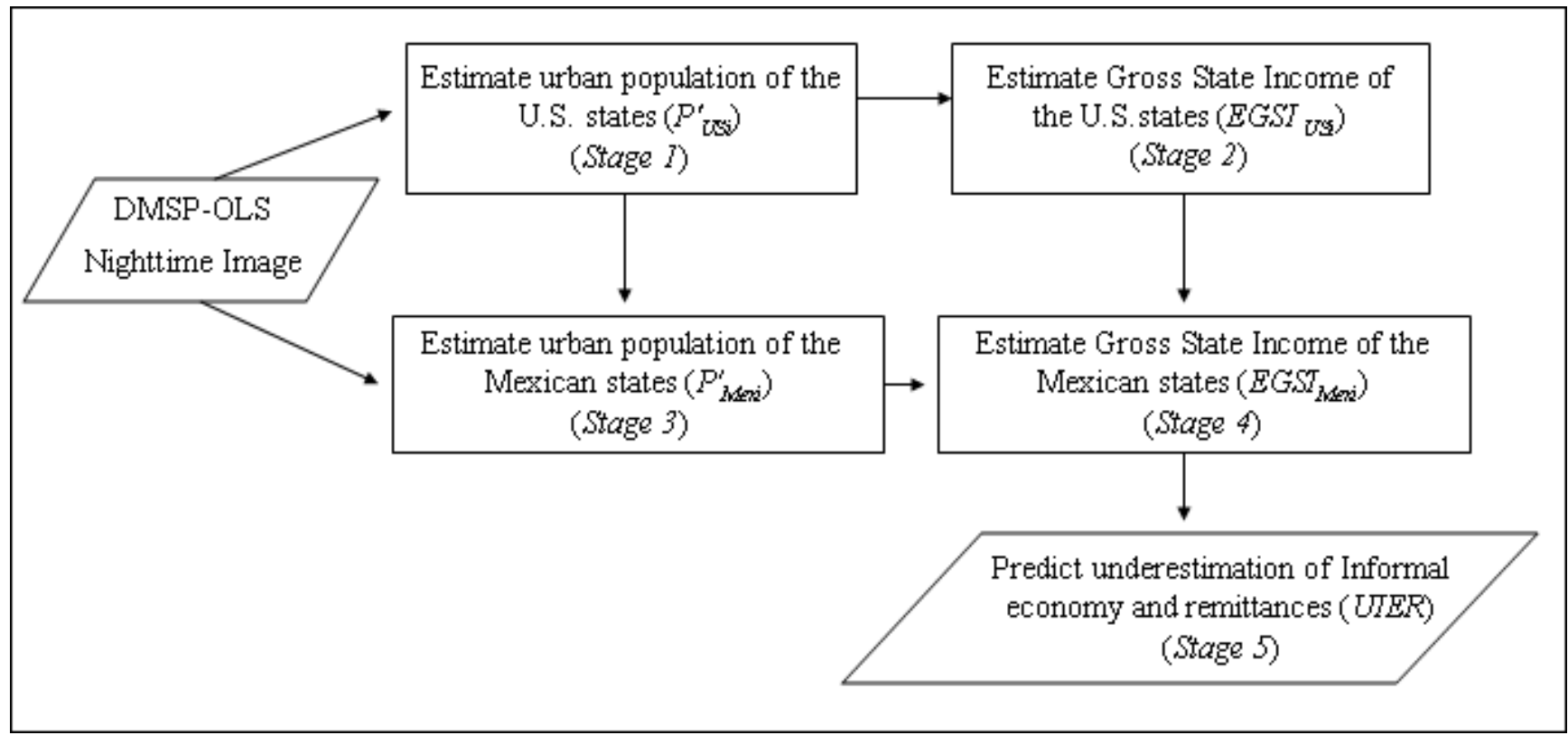

\subsection{Basic Assumptions of the Model}

The model developed to estimate the Gross State Income for each Mexican state $\left(E G S I_{\text {Mex }_{i}}\right)$, Gross Domestic Income $\left(E G D I_{M e x}\right)$, informal economy and remittances for Mexico was trained using the more reliable $A G S P_{U S_{i}}$ for each U.S. state and was based on the following assumptions:

- Urban populations can be estimated based on urban area measured from nighttime lights.

- Because spatially disaggregate GSP data are either unavailable or simply do not exist, estimates of urban populations can serve as a valid proxy measure of the value of economic activity.

- Economic activity associated with urban populations creates the same spatial patterns of nighttime lights in Mexico as in the United States (i.e., there are no cultural, socio-economic, or demographic 'correction factors').

- Spatial patterns of GDP per capita and spatial patterns of distribution of income (i.e., Gini coefficients) are uniform (but not necessarily equivalent) in both the United States and Mexico.

Consequently, a multiple regression model was developed to predict the Gross State Income of the 48 contiguous states of the U.S $\left(E G S I_{U S_{i}}\right)$. These regression parameters, were then applied to the spatial patterns of nighttime lights in Mexico to estimate $E G S I_{M_{e x}}$ for each Mexican state, national $E G D I_{M e x}$, and subsequently the informal economy and remittances of the Mexican states.

\subsection{Model to Predict Urban Population of the U.S. States - Stage 1}

The aim of our analysis was to develop a model to estimate the $E G S I_{\text {Mex }_{i}}$, EGDI $I_{\text {Mex }}$, informal economy and remittances of Mexico based on U.S. parameters. The first stage in the model involved estimating urban population of the U.S. states (Figure 4), based on a modification of the law of allometric growth. The law of allometric growth, originally developed by biologists, states that the 
relative growth of an organ is a constant fraction of the state of relative growth of the total organism [52]. Taking ' $y$ ' to be the organ and ' $x$ ' to be the organism, the law of allometric growth can be expressed as:

$$
y=a x^{b}
$$

where ' $a$ ' and ' $b$ ' are empirical constants. Taking the logarithm of both sides the linear equation is thus:

$$
\ln (y)=\ln (a)+b \times \ln (x)
$$

Based on this law of allometric growth, Tobler [53] established that urban populations (taken as y) could be estimated with a high degree of accuracy by measuring the area of human settlements (taken as $\mathrm{x}$ ) as observed from satellite photography:

$$
\ln (\text { population })=a+b \times \ln (\text { area })
$$

The original application of allometric growth law estimated population of individual urban settlements or cities. We modified this application as we estimated urban populations of the U.S. and Mexico at the state level by aggregating the areas of urban settlements within each state.

The radiance-calibrated DMSP-OLS image of the U.S. was used to delineate the lit urban areas of each U.S. state. We experimented with different brightness thresholds on the nighttime image to determine the brightness threshold that would include urban areas with low population density. The polygons derived by the application of the different thresholds were exported onto Google Earth imagery to determine whether urban areas with low population density were included. The threshold of $20 \times 1.35 \times 10^{-10}$ watts $/ \mathrm{cm}^{2} / \mathrm{sr}$ was empirically determined as the appropriate threshold value. The same threshold was used to delineate the lit urban areas of Mexico.

Urban populations of all lit urban areas included by applying the brightness threshold to the nighttime image of the U.S. were estimated based on the modified law of allometric growth [52,53]. First, areas of the lit urban settlements of each U.S. state $\left(A_{U S_{i}}\right)$, which were demarcated using the threshold, were estimated. The 'thresholded' nighttime image was then used to mask the Landscan population grid in order to extract the urban populations of each U.S. state from the areas demarcated by the brightness threshold $\left(P_{U S_{i}}\right)$. This generated a table of urban settlements that included both area and population attributes. A log-log regression model was used to estimate urban population $\left(P^{\prime} U S_{i}\right)$ for each of the 48 contiguous U.S. states using the area and population attributes. Equation 4 shows the linear model between the natural log of the areal extent of urban areas of the U.S. states and natural log of the population of the U.S. states based on the law of the allometric growth. The regression parameters $\alpha_{1 U S}$ and $\beta_{1 U S}$ derived through this equation were 5.10 and 1.07 , respectively. Urban population of each of the 48 U.S. states was subsequently estimated by the exponentiation of the logarithmic equation (Equation 5) [15]. The regression relationship is presented in Figure 5.

$$
\begin{aligned}
& \ln \left(P_{U S_{i}}\right)=\alpha_{1 U S}+\beta_{1 U S} \times \ln \left(A_{U S_{i}}\right) \\
& P_{U S_{i}}^{\prime}=\exp \left(\alpha_{1 U S}+\beta_{1 U S} \times \ln \left(A_{U S_{i}}\right)\right)
\end{aligned}
$$


Figure 4. Stage 1 of the model: outputs are Estimated urban population of the U.S. states and the corresponding regression model parameters used to estimate the urban population of Mexico in Stage 3.

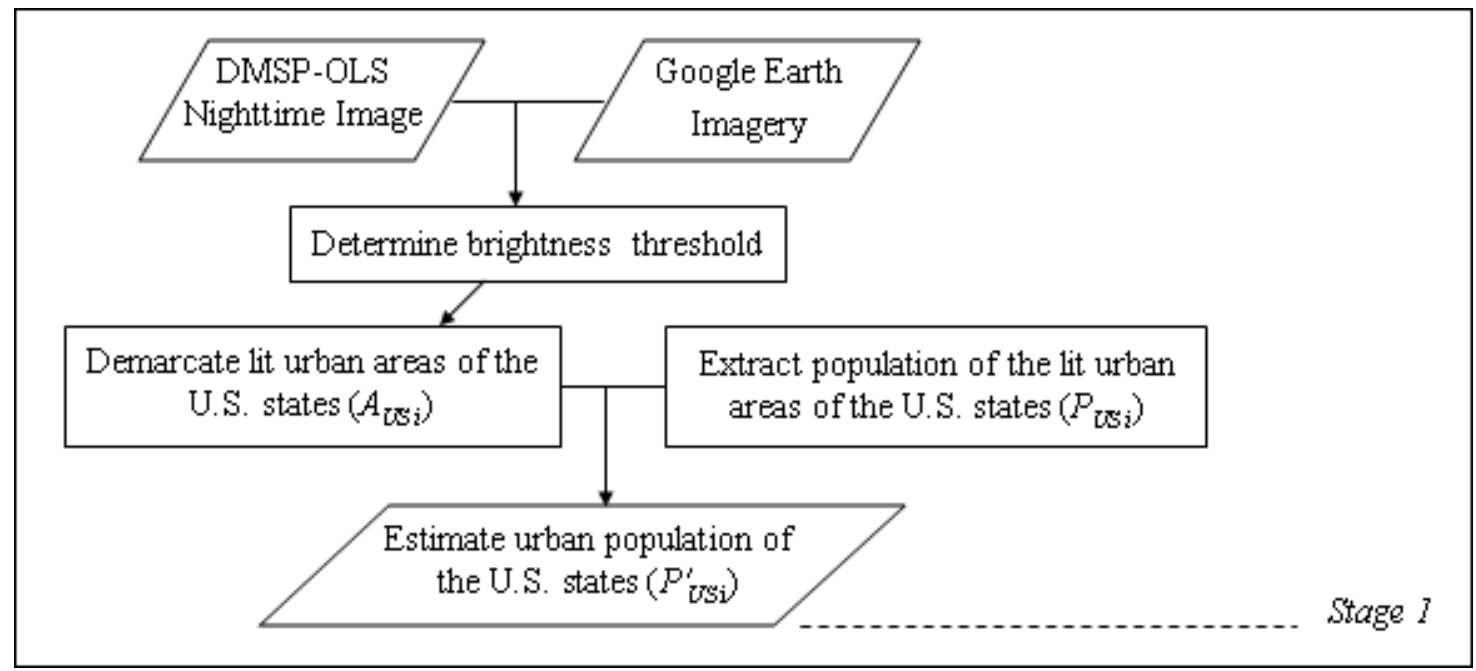

Figure 5. The log-log linear regression model of the area and population of the urban areas for the 48 contiguous U.S. states.

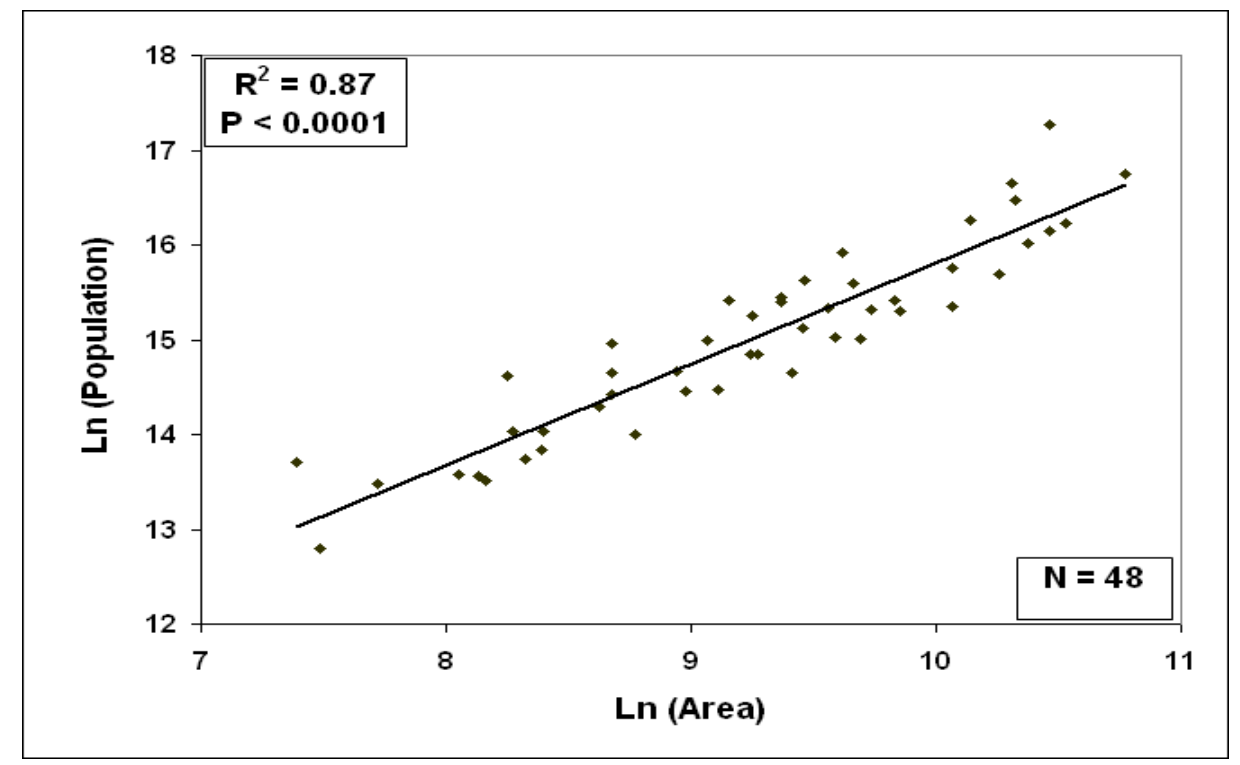

3.4. Model to Predict Gross State Income of the U.S. States - Stage 2

In Stage 2 (Figure 6), a multiple regression model was developed for estimating Gross State Income $\left(E G S I_{U S_{i}}\right)$ for each U.S. state based on the estimated urban populations of the 48 contiguous U.S. states from Stage 1.

The multiple regression model was based on the assumption that estimates of urban populations and activities measured by nighttime lights can serve as a proximate measure of economic activity. The estimated urban population of each of the 48 U.S. states $\left(P^{\prime}{ }_{U S_{i}}\right)$ and the 'sum of lights' for each U.S. state $\left(S_{U S_{i}}\right)$ were the predictors in the regression model (Equation 6). The 'sum of lights' (even those below the threshold level) were calculated in order to include all the economic activities, even those 
outside of 'urban' areas as defined by the brightness threshold. The regression equation was weighted by the Adjusted Gross State Product $\left(A G S P_{U S_{i}}\right)$ for each U.S. state so that states with higher $A G S P_{U S_{i}}$ (like, California and New York) have a greater influence on the equation than the states with lower $A G S P_{U S_{i}}$. The regression parameters, $\alpha_{2 U S}, \beta_{2 U S}$, and $\beta_{3 U S}$ were determined to be $16.11,0.62$, and $2.1 \times 10^{-7}$, respectively. The $E G S I_{U S_{i}}$ for each U.S. state was subsequently estimated by the exponentiation of the logarithmic equation (Equation 7).

$$
\begin{aligned}
& \ln \left(A G S P_{U S_{i}}\right)=\alpha_{2 U S}+\beta_{2 U S} \times \ln \left(P_{U S_{i}}^{\prime}\right)+\beta_{3 U S} \times S_{U S_{i}} \\
& E G S I_{U S_{i}}=\exp \left(\alpha_{2 U S}+\beta_{2 U S} \times \ln \left(P_{U S_{i}}^{\prime}\right)+\beta_{3 U S} \times S_{U S_{i}}\right)
\end{aligned}
$$

Figure 6. Stage 2 of the model: outputs are Estimated Gross State Income of the U.S. states and multiple regression model parameters used to estimate the Gross State Income of the Mexican states in Stage 4 of the model.

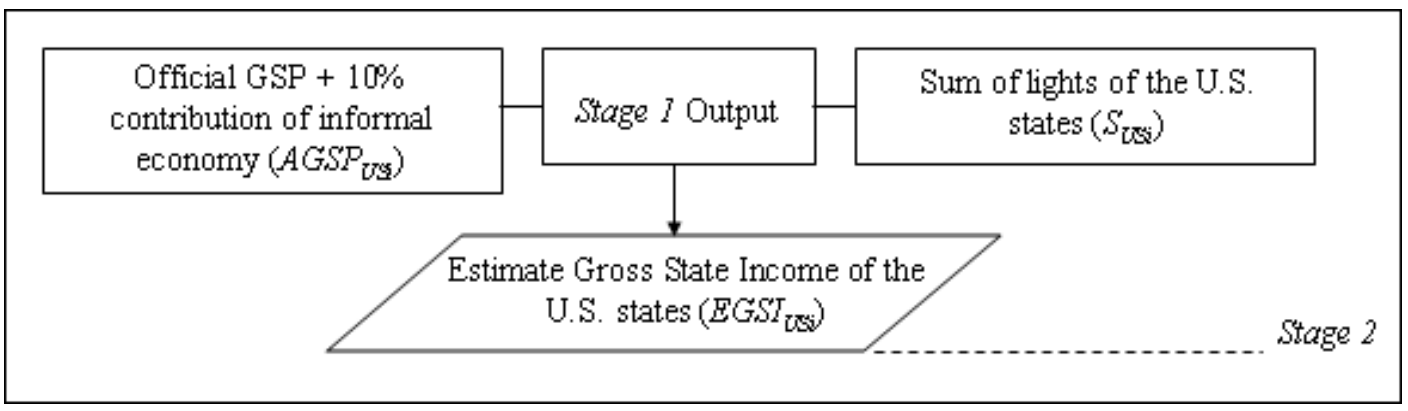

Figure 7 presents the Actual-versus-Predicted plot for the log of the $A G S P_{U S_{i}}$ values. When Actual $\ln \left(A G S P_{U S_{i}}\right)$ (i.e., officially reported statistics) was modeled as a linear function of $\ln \left(P^{\prime} U S_{i}\right)$ and $S_{U S_{i}}$ of the states of the U.S., the resulting model accounted for 81 percent $\left(\mathrm{R}^{2}=0.81\right)$ of observed variance in the Actual $\ln \left(A G S P_{U S_{i}}\right)(\mathrm{P}<0.0001)$.

Figure 7. The actual versus predicted plot of the $\ln (A G S P)$ values of the U.S. states derived from the multiple regression model in which natural log of the estimated urban population and 'sum of lights' are the predictor variables.

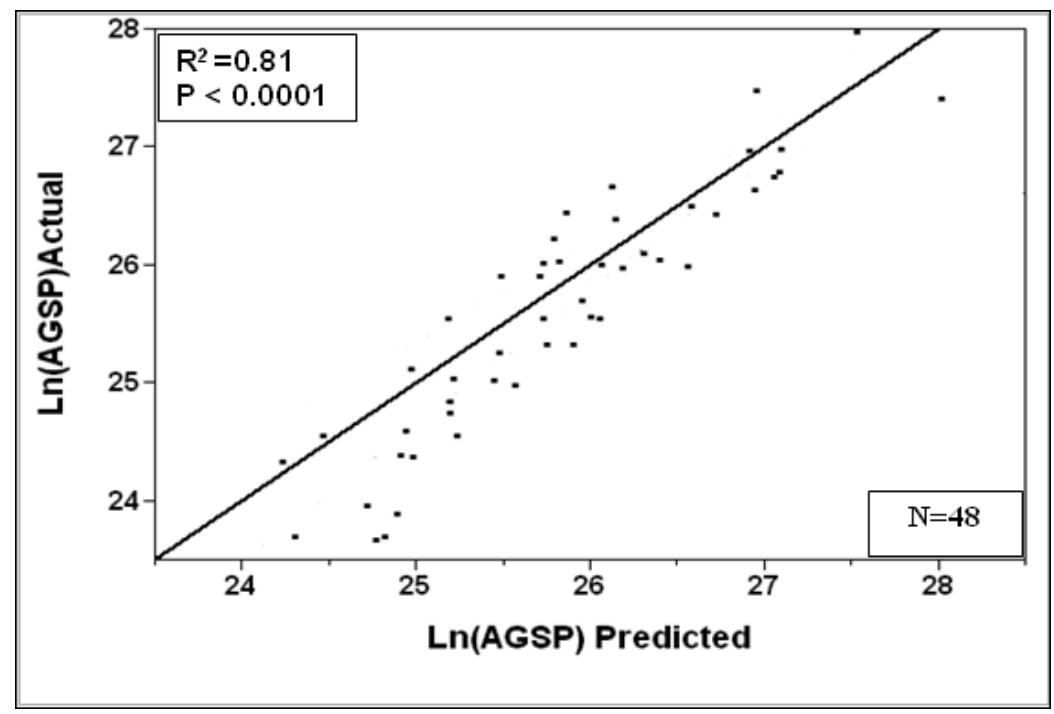


A plot of the official $A G S P_{U S_{i}}$ and modeled $E G S I_{U S_{i}}$ values of the U.S. states is shown in Figure 8. The correlation coefficient (Pearson's $r$ ) between officially reported and modeled estimates is 0.84 , indicating a strong association between the two variables. The modeled $E G S I_{U S_{i}}$ values are close to the official $A G S P_{U S_{i}}$ values for most of the states, with the exception of Texas, New York and California. $E G S I_{U S_{i}}$ was overestimated for Texas and underestimated for New York and California.

Figure 8. Official $A G S P_{U S_{i}}$ versus Modeled $E G S I_{U S_{i}}$ of the U.S. states.

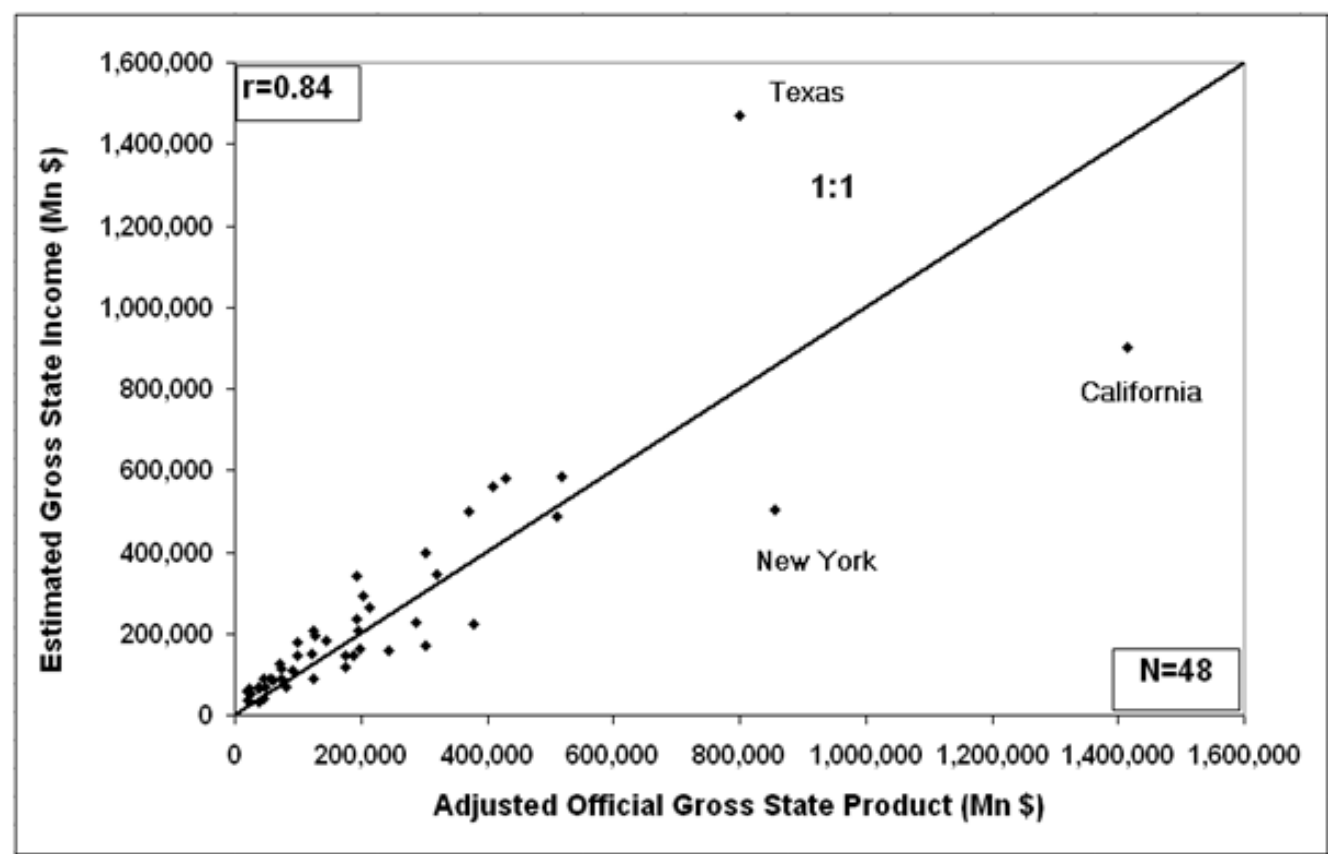

3.5. Estimating the 'U.S. Equivalent urban Population' of the States of Mexico - Stage 3

In Stage 3, the regression parameters of the U.S. derived from Stage 1 were applied to estimate the 'U.S. equivalent urban population' of the Mexican states (Figure 9).

Figure 9. Stage 3 of the model: output is Estimated 'U.S. equivalent urban population' of each Mexican state using the U.S. regression parameters derived from Stage 1.

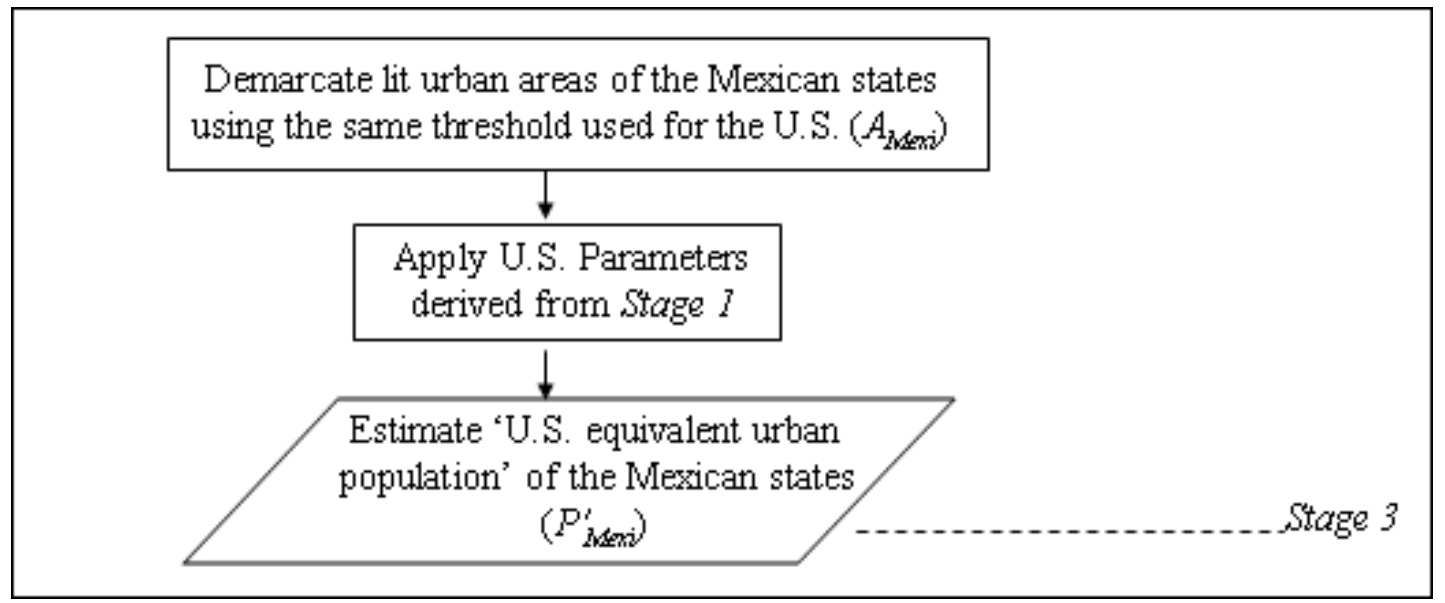


We used the same U.S. brightness threshold to delineate the lit urban areas of Mexico in order to apply the parameters we had estimated for the U.S. and to conform to our assumption that economic activity creates the same spatial patterns of light in the U.S. and in Mexico.

Area of the urban extent for each Mexican state demarcated by the brightness threshold was estimated from the nighttime image $\left(A_{M e x_{i}}\right)$. The regression parameters derived for the U.S. in Stage 1 were applied to Mexico's urban areas to obtain the 'U.S. equivalent population' for the urban areas of each Mexican state $\left(P^{\prime}{ }_{\text {Mex }}\right)$ (Equation 8).

$$
P_{\text {Mex }_{i}}^{\prime}=\exp \left(\alpha_{1 U S}+\beta_{1 U S} \times \ln \left(A_{\text {Mex }_{i}}\right)\right)
$$

\subsection{Estimating Gross State Income of the states of Mexico - Stage 4}

In Stage 4 (Figure 10), the Gross State Income for each Mexican state was estimated. The same regression model which was developed for the U.S. was used to estimate the $E G S I_{\text {Mexi }_{i}}$ of each Mexican state using the 'sum of lights' for each Mexican state $\left(S_{\text {Mex }_{i}}\right)$ and estimated urban population of each Mexican state (Equation 9).

$$
E G S I_{\text {Mex }_{i}}=\exp \left(\alpha_{2 U S}+\beta_{2 U S} \times \ln \left(P_{\text {Mex }_{i}}^{\prime}\right)+\beta_{3 U S} \times S_{\text {Mex }_{i}}\right)
$$

Figure 10. Stage 4 of the model: output is the Estimated Gross State Income of the Mexican states using the U.S. regression parameters derived from Stage 2.

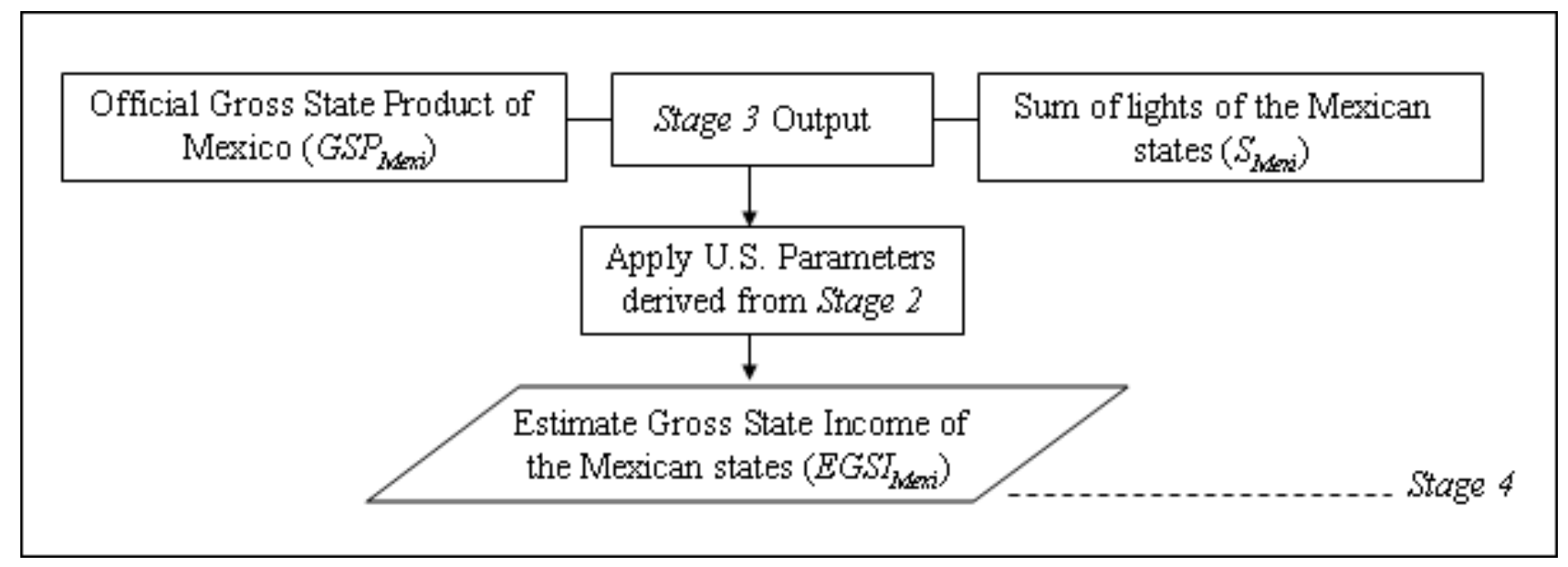

$E G S I_{M e x_{i}}$ of each Mexican state derived from the DMSP-OLS image was assumed to include the formal economy, informal economy, and the estimates of the remittance inflow into Mexico. EGSI Mex $_{i}$ should therefore be compared to the official GNI values; however GNI values for Mexico are not available at the state level. Additionally, the contribution of the remittances reported by Banco de Mexico is only 0.8 percent of the official GNI that is reported by INEGI for the year 2000 . Thus, we concluded that $E G S I_{M e x_{i}}$ (which we assumed to include remittances) and the official GSP values $\left(G S P_{M e x_{i}}\right.$, which do not include remittances) were comparable. In Figure 11, Modeled $E G S I_{M_{e x}}$ was plotted against the official GSP Mex $_{i}$ for each Mexican state (Figure 11), excluding Distrito Federal or Mexico City. However, although Mexico City was not shown in Figure 11, it was taken into account in the calculation of the national Estimated Gross Domestic Income $\left(E G D I_{M e x}\right)$ and in the final 
computation of the underestimated informal economy and remittances. The plot shows that $G S P_{\text {Mex }_{i}}$ was overestimated for 27 of the Mexican states and underestimated for one state. The Pearson's correlation coefficient (r) of the official $G S P_{\text {Mex }_{i}}$ versus modeled $E G S I_{M e x_{i}}$ is 0.87 , indicating a strong association between the two variables.

Figure 11. Official $G S P_{\text {Mex }_{i}}$ versus Modeled $E G S I_{M e x_{i}}$ of the Mexican states, excluding Distrito Federal.

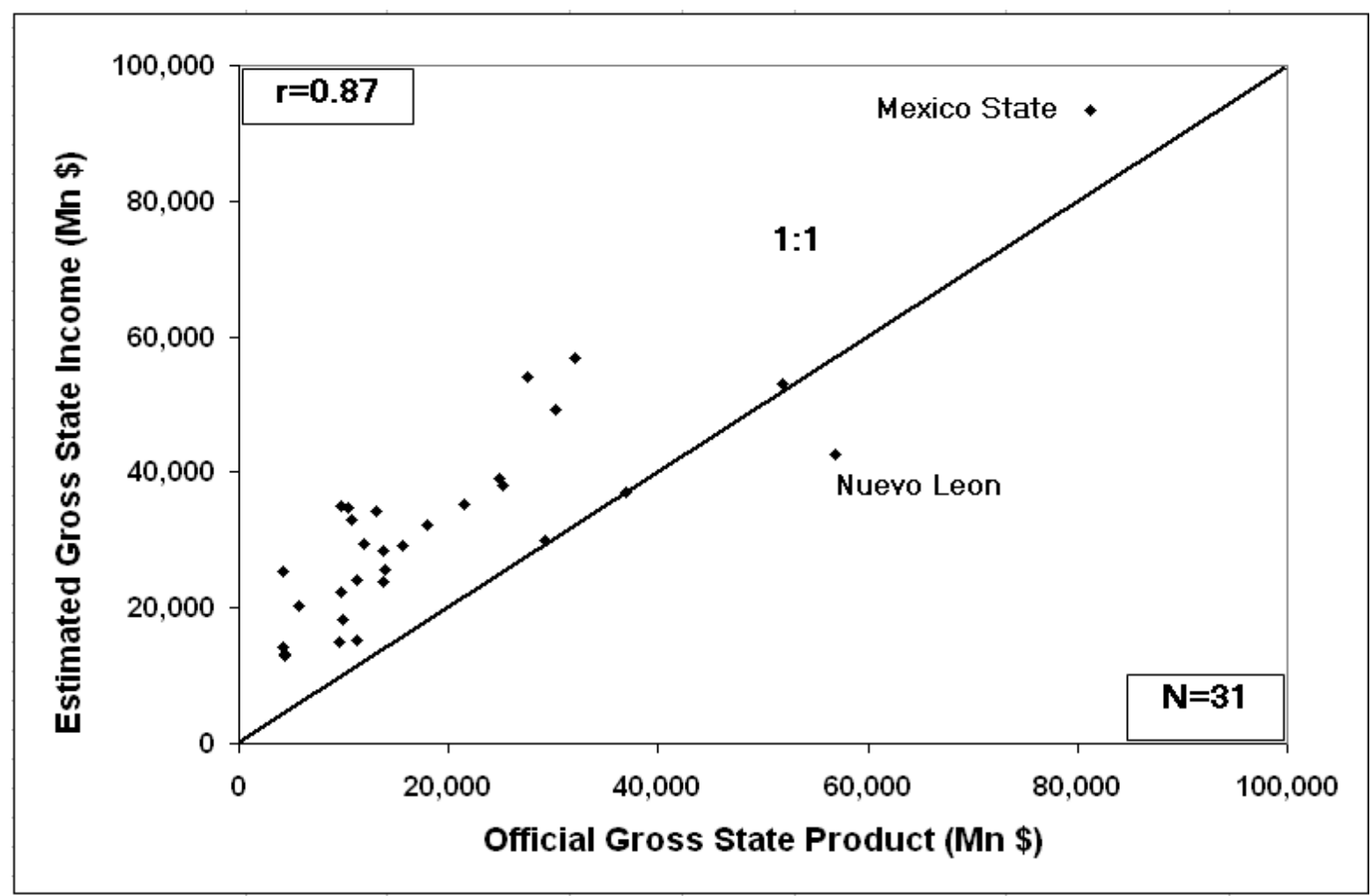

3.7. Estimating the Magnitude and Spatial Distribution of the Informal Economy and Remittances of Mexico and Comparing It with the Published Values - Stage 5

The final stages in the analysis involved estimating the magnitude of informal economy and remittances of Mexico (Figure 12). The $E G S I_{M_{e x}}$ values derived from nighttime lights data for each state were summed to estimate Gross Domestic Income $\left(E G D I_{M e x}\right)$ for all of Mexico. $E G D I_{M e x}$ was compared to the official GNI value of Mexico $\left(G N I_{M e x}\right)$. Both $E G D I_{M e x}$ and $G N I_{M e x}$ include the formal economy, informal economy and the inflow of remittances into the economy. We assumed that remittances are included in the nighttime-lights derived $E G D I_{M e x}$ estimates because the residents of Mexico use the money sent to them as remittances to purchase basic amenities and energy, and therefore, improvement in the economy should be measureable from the nighttime lights. Subtracting the $E G D I_{M e x}$ from the official $G N I_{M e x}$ gave the predicted underestimation of informal economy and remittances (UIER) in the official estimates of $G N I_{M e x}$ (Equation 10):

$$
U I E R=E G D I_{M e x}-G N I_{M e x}
$$


Figure 12. Stage 5 of the model: output is predicted underestimation of the informal economy and remittances in the official GNI estimates.

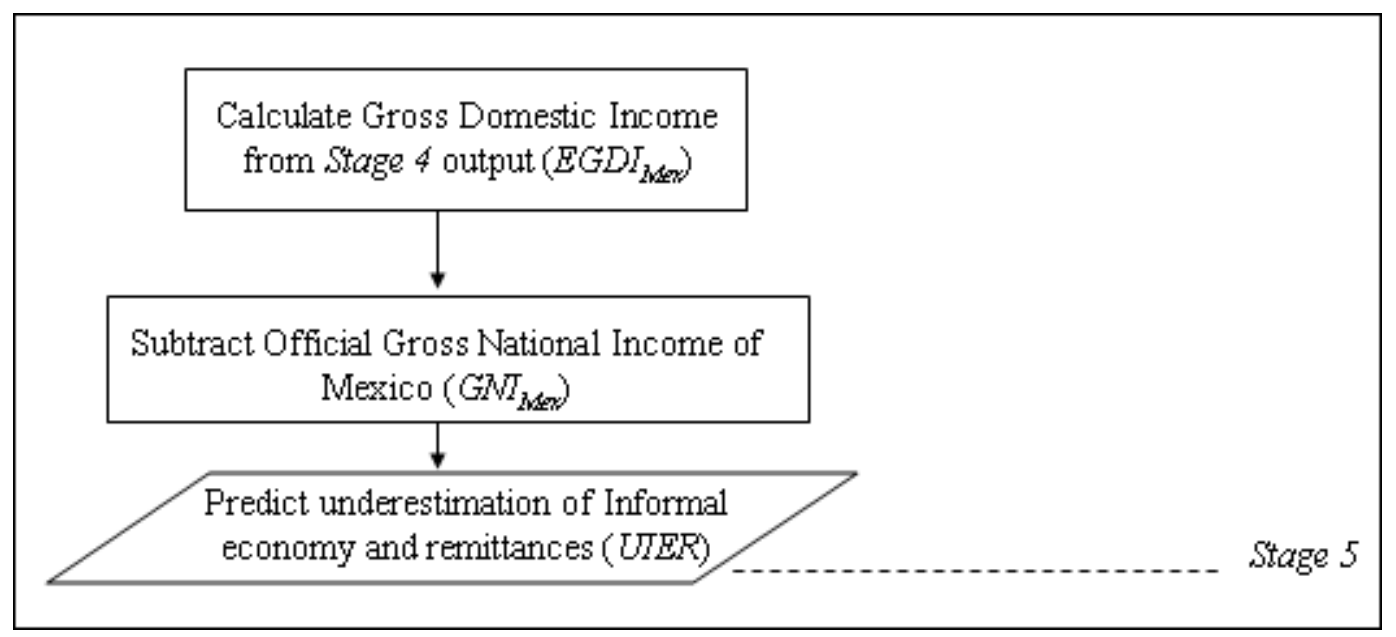

\section{Results}

\subsection{Official AGSP and modeled EGSI of the U.S.}

The log linear relationship between the aggregated area of urban clusters and population of the U.S. states provided estimates of the urban populations for the U.S. states. A multiple linear regression model was trained using the $A G S P_{U S_{i}}$, to predict economic activity based on population and extent of lights. The residual percentage of each U.S. state $\left(\right.$ Residual $\left._{U S i}\right)$ was calculated (Equation 11, Table 5) and mapped in Figure 13 to get a clear picture of the degree to which the $E G S I_{U S_{i}}$ was over- or underestimated for each state.

$$
\operatorname{Residual}_{U S_{i}}=\frac{A G S P_{U S_{i}}-E G S I_{U S_{i}}}{A G S P_{U S_{i}}} \times 100
$$

$E S_{U_{S}}$ was severely overestimated (having the highest negative residuals) for the states of Montana, North Dakota, South Dakota and Wyoming. These are also the states with the lowest official estimates of AGSP $U_{U S_{i}}$. Texas, New York and California are outliers, with $E G S I_{U S_{i}}$ being overestimated for Texas and underestimated for California and New York (Figure 8). These are also the three states with the highest official estimates of $A G S P_{U S_{i}}$ : California, New York and Texas, in that order. The $E G S I_{U S_{i}}$ of Texas may have been overestimated because of the prevalence of gas flares which can be confused with urban extent on the nighttime lights imagery. The underestimation in California and New York may be due to their coastal location and the resulting constraint on urban sprawl. Sutton [54] has suggested that the higher costs of coastal lands and the pressure to utilize coastal land intensively have probably restricted urban sprawl. This might result in smaller than expected urban area given the populations of California and New York, and thus lower the estimates of their $E G S I_{U S_{i}}$ from the nighttime image. Elvidge et al. [40] had observed the same outliers in their plot of population versus cumulative radiance from 1996-1997 radiance calibrated DMSP-OLS data and had attributed the anomalous darkness of California and New York relative to their population (and subsequently $E G S I_{U S_{i}}$ in this analysis) to the presence of large densely populated areas in New York City and the Los Angeles Region. 
Table 5. Official $A G S P_{U S_{i}}$, Modeled $E G S I_{U S_{i}}$, and Percentage Residual for each U.S. state.

\begin{tabular}{|c|c|c|c|}
\hline U.S. States & 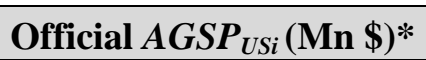 & ${\text { Modeled } E G S I_{U S i}(\text { Mn \$) }}$ & Percentage Residual \\
\hline Alabama & 126,034 & 195,001 & -55 \\
\hline Arizona & 174,386 & 147,181 & 16 \\
\hline Arkansas & 73,481 & 112,061 & -53 \\
\hline California & $1,415,860$ & 900,485 & 36 \\
\hline Colorado & 189,048 & 147,449 & 22 \\
\hline Connecticut & 176,480 & 116,503 & 34 \\
\hline Delaware & 45,619 & 41,909 & 8 \\
\hline Florida & 518,448 & 583,857 & -13 \\
\hline Georgia & 319,976 & 343,800 & -7 \\
\hline Idaho & 38,488 & 70,333 & -83 \\
\hline Illinois & 510,613 & 488,257 & 4 \\
\hline Mexicona & 213,861 & 263,892 & -23 \\
\hline Iowa & 99,205 & 176,838 & -78 \\
\hline Kansas & 91,093 & 111,667 & -23 \\
\hline Kentucky & 123,090 & 149,209 & -21 \\
\hline Louisiana & 144,672 & 182,660 & -26 \\
\hline Maine & 39,096 & 65,478 & -67 \\
\hline Maryland & 198,404 & 161,638 & 19 \\
\hline Massachusetts & 302,444 & 170,528 & 44 \\
\hline Michigan & 370,959 & 499,804 & -35 \\
\hline Minnesota & 203,602 & 290,706 & -43 \\
\hline Mississippi & 70,693 & 126,428 & -79 \\
\hline Missouri & 194,379 & 208,637 & -7 \\
\hline Montana & 23,503 & 64,156 & -173 \\
\hline Nebraska & 61,026 & 86,850 & -42 \\
\hline Nevada & 81,091 & 69,500 & 14 \\
\hline New Hampshire & 47,870 & 67,358 & -41 \\
\hline New Jersey & 379,306 & 221,632 & 42 \\
\hline New Mexico & 55,798 & 87,387 & -57 \\
\hline New York & 854,873 & 505,191 & 41 \\
\hline North Carolina & 301,068 & 399,836 & -33 \\
\hline North Dakota & 19,527 & 59,650 & -205 \\
\hline Ohio & 409,207 & 560,518 & -37 \\
\hline Oklahoma & 98,733 & 148,215 & -50 \\
\hline Oregon & 123,682 & 88,137 & 29 \\
\hline Pennsylvania & 428,581 & 579,311 & -35 \\
\hline Rhode Island & 36,970 & 33,301 & 10 \\
\hline South Carolina & 123,765 & 205,450 & -66 \\
\hline South Dakota & 25,409 & 54,191 & -113 \\
\hline Tennessee & 192,336 & 236,374 & -23 \\
\hline Texas & 799,956 & $1,469,456$ & -84 \\
\hline Utah & 74,325 & 89,223 & -20 \\
\hline Vermont & 19,560 & 35,674 & -82 \\
\hline Virginia & 286,817 & 226,155 & 21 \\
\hline
\end{tabular}


Table 5. Cont.

\begin{tabular}{lccc}
\hline Washington & 244,157 & 157,625 & 35 \\
West Virginia & 45,624 & 90,620 & -99 \\
Wisconsin & 193,311 & 342,603 & -77 \\
Wyoming & 19,064 & 56,666 & -197 \\
\hline
\end{tabular}

*Source: U.S. Census Bureau, U.S. Bureau of Economic Analysis, 2000

Figure 13. Map of the Percentage Residual Gross State Product by U.S. state.

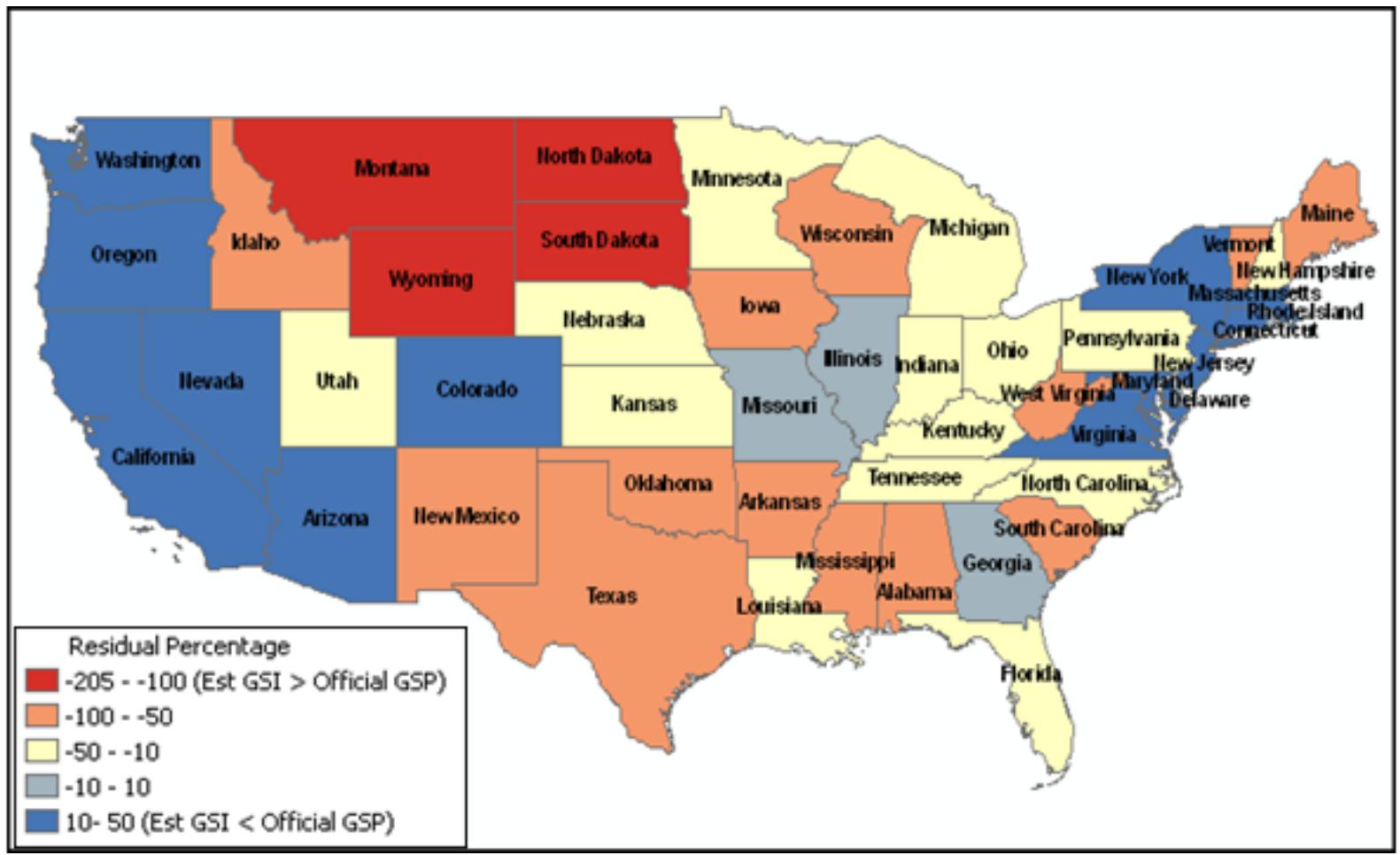

\subsection{Official GSP and Modeled GSI of Mexico}

The residual percentages of the Gross State Product $\left(G S P_{M e x_{i}}\right)$ of each Mexican state derived from the model using U.S. parameters showed an overestimation of $E G S I_{M e x_{i}}$ for all the states except for Distrito Federal and Nuevo Leon (Table 6). Underestimation of EGSI Mex $_{i}$ was the greatest for Distrito Federal (86 percent). The percentage residual map of Mexico is shown in Figure 14.

Table 6. Official GSP $P_{M e x}$, Modeled $E G S I_{M e x_{i}}$ and Percentage Residual for each Mexican state.

\begin{tabular}{lccc}
\hline Mexican States & $\begin{array}{c}\text { Official GSP } \\
\text { U.S. } \text { Mn } \mathbf{~ \$ )}\end{array}$ & $\begin{array}{c}\text { Modeled } \text { EGSI }_{\text {Mexi }} \\
\text { (PPP U.S. Mn \$) }\end{array}$ & $\begin{array}{c}\text { Percentage } \\
\text { Residual }\end{array}$ \\
\hline Aguascalientes & 9,948 & 18,287 & -84 \\
Baja California & 29,174 & 30,004 & -3 \\
Baja California Sur & 4,349 & 13,050 & -200 \\
Campeche & 9,606 & 15,027 & -56 \\
Chiapas & 13,096 & 34,176 & -161 \\
Chihuahua & 36,863 & 37,157 & -1 \\
Coahuila & 25,109 & 38,197 & -52 \\
\hline
\end{tabular}


Table 6. Cont.

\begin{tabular}{lccc}
\hline Colima & 4,394 & 13,172 & -200 \\
Distrito Federal & 180,940 & 25,270 & 86 \\
Durango & 9,665 & 22,288 & -131 \\
Guanajuato & 27,558 & 54,015 & -96 \\
Guerrero & 13,819 & 28,445 & -106 \\
Hidalgo & 10,479 & 34,686 & -231 \\
Jalisco & 51,808 & 53,011 & -2 \\
Mexico & 81,147 & 93,334 & -15 \\
Michoacan & 17,892 & 32,160 & -80 \\
Morelos & 10,728 & 33,067 & -208 \\
Nayarit & 4,255 & 14,286 & -236 \\
Nuevo Leon & 56,923 & 42,575 & 25 \\
Oaxaca & 11,916 & 29,470 & -147 \\
Puebla & 30,228 & 49,212 & -63 \\
Queretaro & 13,925 & 25,636 & -84 \\
Quintana Roo & 11,253 & 15,299 & -36 \\
San Luis Potosi & 13,834 & 23,969 & -73 \\
Sinaloa & 15,576 & 29,178 & -87 \\
Sonora & 21,494 & 35,341 & -64 \\
Tabasco & 9,721 & 35,138 & -261 \\
Tamaulipas & 24,888 & 39,162 & -57 \\
Tlaxcala & 4,276 & 25,332 & -492 \\
Veracruz & 31,975 & 56,804 & -78 \\
Yucatan & 11,166 & 24,022 & -115 \\
Zacatecas & 5,784 & 20,367 & -252 \\
\hline & $1, E G 1$, &
\end{tabular}

* Source: INEGI, Total de la actividad economica, 2000

Figure 14. Map of the Percentage Residual Gross State Product by Mexican state.

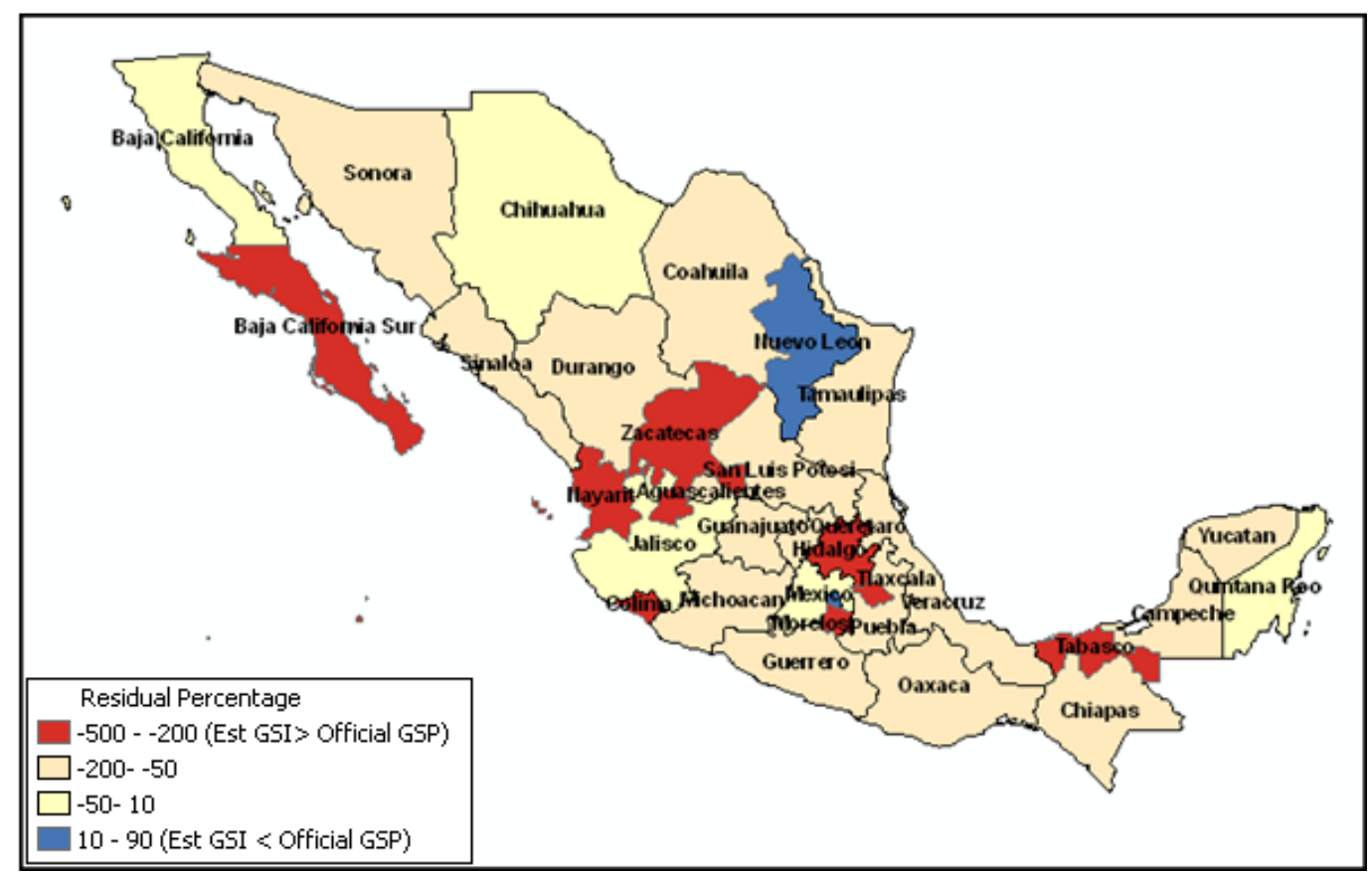


4.3. Estimating the Magnitude of Underestimation of Informal Economy and Remittances in the Official Measures of GNI of Mexico

The $E G D I_{M e x}$ of Mexico (sum of the state $E G S I_{M_{e x}}$ values of each Mexican state) was approximately U.S. $\$ 1,041$ billion (Row 1 of Table 7). This figure was assumed to include the formal economy, informal economy and remittances. The official GNI of Mexico $\left(G N I_{M e x}\right)$ for 2000 was approximately PPP U.S. $\$ 886$ billion (Row 2 of Table 7). Subtracting the $G N I_{M e x}$ from $E G D I_{M e x}$ gave the predicted underestimation of informal economy and remittances in the official estimates (Row 3 of Table 7). In order to derive the magnitude of underestimation, we first summed the official estimates of informal economy and remittances for the year 2000 (Row 6 of Table 7). Then, we divided the predicted value of informal economy and remittances (Row 7 of Table 7) by the sum of the official estimates of informal economy and remittances (Row 8 of Table 7). The result demonstrated that the informal economy and inflow of remittances for Mexico was about 150 percent larger than what was recorded in the official estimates of Gross National Income $\left(G N I_{M e x}\right)$.

Table 7. Determining the magnitude of underestimation of informal economy and remittances in the official estimates of GNI of Mexico.

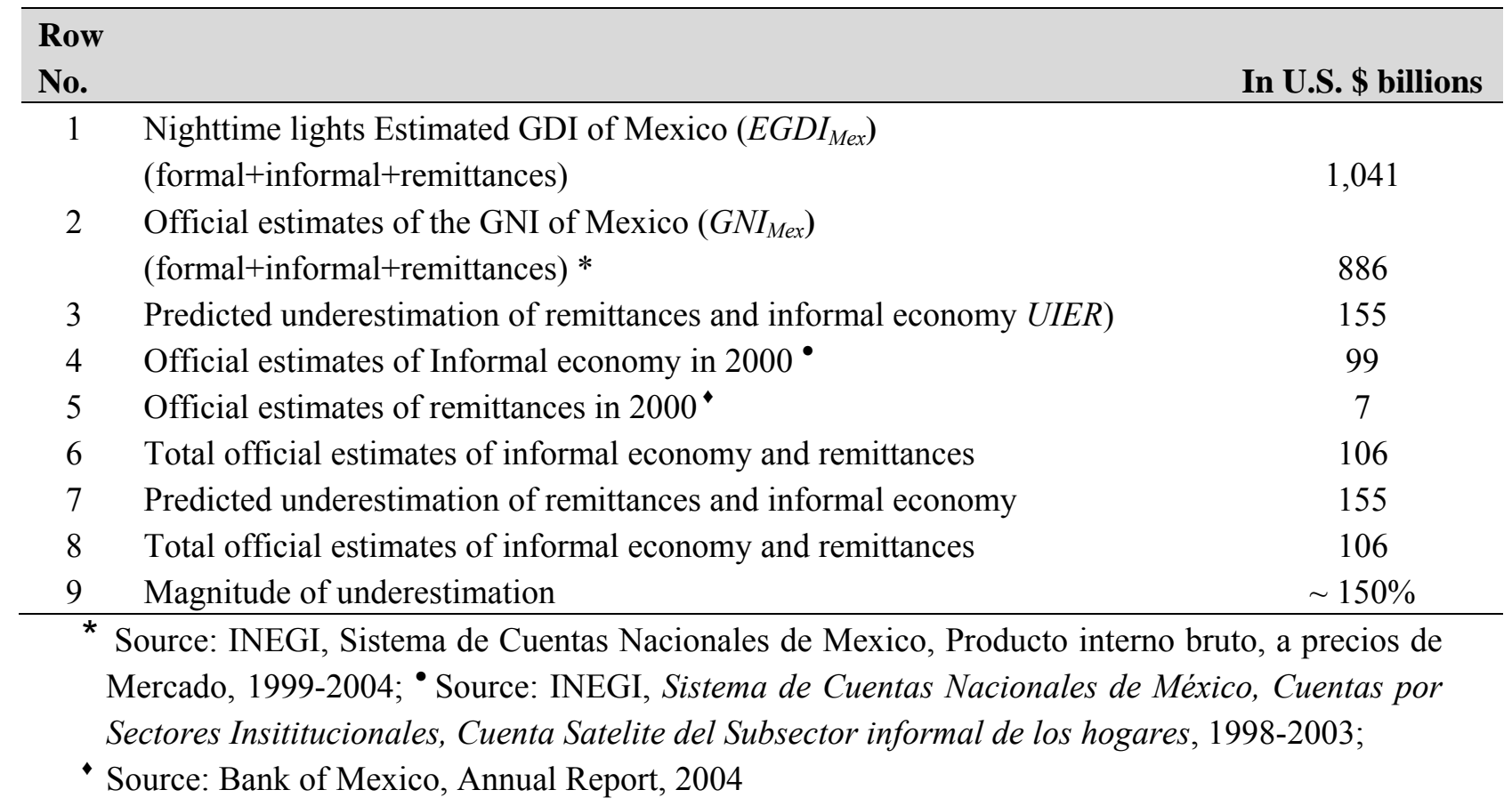

\section{Discussion}

The radiance calibrated nighttime image of 2000-2001 and the $A G S P_{U S_{i}}$ of each U.S. state was used to develop a regression model for estimating $E G S I_{M_{e x}}$ for each of the Mexican states. The $E G D I_{M e x}$ was compared to the official estimate of $G N I_{M e x}$. We found that most states in Mexico have more lighting compared to their officially reported GSP would suggest. We explored the idea that this surplus in lighting could be attributed to the informal economy and inflow of remittances in Mexico. Our conclusion that the informal economy in Mexico may be larger than the existing official estimates (12 percent of GDP) has been corroborated in several studies which have used different methods to 
estimate the informal economy of countries. Schneider and Enste [55] had estimated the informal economy of Mexico to be varying between 27 percent and 49 percent of GDP using other commonly used approaches (Physical Input or Electricity Consumption method, Currency Demand approach and the Multiple Indicators and Multiple Causes (MIMIC) model). Vuletin [56] estimated the informal economy of Mexico to be 28 percent of GDP using the MIMIC approach. Although some of the disaggregated $G D P$ values of the states of Mexico have large residual errors, the power of the mean strengthens our argument that the informal/remittance economy of Mexico is larger than the official estimates.

The model developed to estimate the spatially disaggregate Gross State Incomes of the U.S. states $\left(E G S I_{U S_{i}}\right)$ demonstrates that the model, in general, tends to underestimate the Gross State Incomes $(G S I)$ of states with high official values of Gross State Product $(G S P)$ relative to their population or relative to lit area. This was observed in the anomalous darkness of New York and California in the U.S. and of Mexico City in the Mexican Republic. Thus, while we assumed that estimated urban population from spatial patterns of light can serve as a proxy measure of economic activity, we observed through the analysis that, in the case of densely populated states with high levels of economic development, estimated urban population from lights tended to underestimate 'money' or economic activity in the richest states. One possible explanation for the underestimation of urban population is that population (and economic activity) is so dense in these states that urban population (and economic activity) is underestimated based on lit urban areas.

Because of the anomalous darkness of Mexico City relative to its level of economic development and population numbers, it has an outlier effect and is not shown in Figure 11. Figure 11 demonstrates how well the modeled $E G S I_{M e x_{i}}$ is associated with the official $G S P_{M e x_{i}}$ along with a 1:1 line. Except for Mexico City, the official $G S P_{\text {Mex }_{i}}$ plotted against $E G S I_{\text {Mex }_{i}}$ shows a strong association with a Pearson's correlation coefficient of 0.87 . Mexico City, being a primate city and the most important economic hub in the Mexican Republic, produces 21.8 percent of the country's GDP [57]. The city's GDP per capita is the highest of any city in Latin America [58]. Although Mexico City has high levels of economic development, the EGSI of Mexico City from the nighttime lights image is underestimated by 86 percent in comparison to the official GSP estimate. The inclusion of Mexico City lowers the correlation coefficient between the official $G S P_{M e x_{i}}$ and modeled $E G S I_{\text {Mex }_{i}}$ values. Therefore, Mexico City is not shown in Figure 11 but is included in the calculation of the Estimated Gross Domestic Income for Mexico $\left(E G D I_{M e x}\right)$ and in the final computation of the underestimation of informal economy and remittances in the official estimate of GNI of Mexico $\left(G N I_{M e x}\right)$.

The existing indirect approaches for estimating informal economy, e.g., the Currency Demand Approach, the physical input (Electricity Consumption Method) and the Multiple Causes and Multiple Indicators (MIMIC) model rely on multiple official, survey-based datasets [54,55]. Our method, on the other hand, provides an independent estimate of economic statistics for Mexico. An interesting area for future research would be to compare the informal economy estimates derived from the existing indirect approaches and our method of estimation from nighttime satellite imagery. By using the indirect approaches in complement with nighttime satellite imagery it may be possible to make further improvements in the estimation of informal economy. Better correlations might have been obtained if we had used Mexican population or economic data, but that would become circular and defeated the purpose of developing an independent methodology for estimating economic statistics. 
Worldwide, collection of official data are often hindered by the differences in the bureaucratic capacity of states, the economic and political situations in countries, the inconsistency of data record keeping practices, and the integrity and sincerity of state officials who are engaged with data collection [49]. These shortcomings in the collection of official data underscore the importance of developing an independent method of estimating economic activity. Results derived from our analysis using the spatial pattern of lights on the DMSP-OLS satellite-derived data provide an objective estimate of economic activity. Moreover, we provide a standardized methodology for estimating economic activities of all countries of the world, as well as the potential for measuring disaggregate economic activity at the sub-national level.

\section{Conclusions}

This research focuses on developing a model for estimating the location and magnitude of GSP, informal economy and remittances for the upper middle income country of Mexico. The model is developed on the basis of the spatial patterns of nighttime satellite imagery and is trained by using the Adjusted Official Gross State Product $\left(A G S P_{U S_{i}}\right)$ for the U.S. states. The result obtained by subtracting the official $G N I$ estimate of Mexico $\left(G N I_{M e x}\right)$ from the estimated Gross Domestic Income $\left(E G D I_{M e x}\right)$ suggest that the informal economy and inflow of remittances into Mexico may be approximately 150 percent larger than what is officially recorded in the published official GNI estimate of Mexico $\left(G N I_{M e x}\right)$.

However, this method is clearly still in the 'exploratory' stage. Our initial results suggest that further research using other countries, finer resolution imagery, and more accurate spatially disaggregate economic numbers will improve the validity of this approach. The increased spatial, spectral and radiometric resolution of future and potential nighttime satellite missions (Visible Infrared Imaging Radiometer Suite and Nightsat) [59] may dramatically improve these methods. Moreover, if we could obtain reliable spatially disaggregate $G D P$ values for a sample of countries at different levels of development, instead of depending on the GSP and GDP estimates of only a developed country, we could potentially build separate models for Upper-, Middle- and Low-Income countries. This would perhaps generate improved, spatially explicit estimates of GSP, GDP, informal economy and remittances for countries at different levels of development.

The informal economy is expanding in Mexico after the economic restructuring following NAFTA. The difficulties associated with collecting informal economic data and the lack of international standards to compare data on informal economy further hinders the proper estimation of informal economy. Many of these problems can be overcome by developing simple and independent methods for estimating and mapping economic activity.

Taking into consideration the continuous growth of population, the ever-changing economy in the era of globalization, the instability associated with informal economic activity and unrecorded remittances, we can anticipate that there will always be an issue with regards to the credibility of the official estimates of informal economic activity and remittances. Therefore, models derived from nighttime imagery may prove useful for estimating population distribution and associated socioeconomic variables for decades to come. This may help economists and policy makers understand the economic situations of countries, detect the shortcomings in economic structures, improve 
employment opportunities, reduce poverty and undertake other constructive economic development policies.

\section{Acknowledgements}

Very special thanks to all my colleagues and friends in the Earth Observation Group, National Geophysical Data Center, National Oceanic and Atmospheric Administration - Kimberly Baugh, Ben Tuttle and Daniel Ziskin for their contributions to this study.

\section{References}

1. Standing, G. Global Labour Flexibility: Seeking Distributive Justice; MacMillan: Basingstoke, UK, 1999.

2. Chen, M.A.; Jhabvala, R.; Lund, F. Working Paper on the Informal Economy, Supporting Workers in the Informal Economy: A Policy Framework; International Labour Office: Geneva, Switzerland, 2002.

3. Chen, M.A. Rethinking the Informal Economy. Seminar Issue of the Symposium of Footloose Labour, 2003; Available online: http:/www.Mexico-seminar.com/2003/531/531\%20martha\%20 alter\%20chen.htm (accessed on 14 May 2009).

4. Women in Informal Employment: Globalizing and Organizing, 2007; Available online: http://www.wiego.org/about_ie/causes\%20and\%20consequences.php (accessed on 14 May 2009).

5. International Labor Organization (ILO). Labour Overview: Latin America and the Caribbean; ILO: Lima, Peru, 2002.

6. Portes, A.; Roberts, B. The Free-market City: Latin American Urbanization in the Years of the Neoliberal Experiment. Stud. Comp. Int. Develop. 2005, 40, 43-82.

7. Jonakin, J. Cycling between Vice and Virtue: Assessing the Informal Sector's Awkward Role Under Neoliberal Reform. Rev. Int. Pol. Econ. 2006, 13, 290-312.

8. International Labor Organization (ILO). Labour Overview: Latin America and the Caribbean; ILO: Lima, Peru, 2005.

9. Marquez, G.; Chong, A.; Duryea, S.; Mazza, J.; Nopo, H. Outsiders? The Changing Pattern of Exclusion in Latin America and the Caribbean; Inter-American Development Bank: Washington, DC, USA, 2007.

10. Biles, J. Informal Work and Livelihoods in Mexico: Getting By or Getting Ahead? Prof. Geogr. 2008, 60, 541-555.

11. Freije, S. Informal Employment in Latin America and the Caribbean: Causes, Consequences and Policy Recommendations; Inter-American Development Bank: Washington, DC, USA, 2001; Available online: http://www.iadb.org/sds/doc/SOCInfEmployment.pdf (accessed on 14 May 2009).

12. Chen, M.A. Rethinking the Informal Economy: Linkages with the Formal Economy and the Formal Regulatory Environment, Working Paper No. 46, U.N. Department of Economic and Social Affairs, 2007; Available from: http://www.un.org/esa/desa/papers/2007/wp46_2007.pdf (accessed on 14 May 2009). 
13. World Bank. Trends, Determinants and Macroeconomic Effect of Remittances, Global Economic Prospects; World Bank: Washington, DC, USA, 2006; pp. 85-112.

14. Ebener, S.; Murray, C.; Tandon, A.; Elvidge, C.D. From Wealth to Health: Modeling the Distribution of Income per Capita at the Sub-national Level Using Nighttime Light Imagery. Int. J. Health Geogr. 2005, 4, 1-17.

15. Sutton, P.C.; Elvidge, C.D.; Ghosh, T. Estimation of Gross Domestic Product at Sub-national Scales Using Nighttime Satellite Imagery. Int. J. Ecol. Econ. Stats. 2007, 8, 5-21.

16. Porter, E. China Shrinks. New York Times, December 9, 2007; Available online: http://www.nytimes.com/2007/12/09/opinion/09sun4.html?_r=1\&th\&emc=th\&oref=slogin (accessed on 14 May 2009).

17. Ahmad, S. Improving Inter-spatial and Inter-temporal Comparability of National Accounts. J. Dev. Eco. 1994, 44, 53-75.

18. Lo, C.P. Applied Remote Sensing; Longman: Harlow, Essex, UK, 1986.

19. Sutton, P.C.; Roberts, D.; Elvidge, C.D.; Meij, H. A Comparison of Nighttime Satellite Imagery and Population Density for the Continental United States. Photogrammteric Eng. Remote Sens. 1997, 63, 1303-1313.

20. Doll, C.N.H. CIESIN Thematic Guide to Night-time Light Remote Sensing and its Applications, Center for International Earth Science Information Network of Columbia University: Palisades, New York, USA, 2008; Available online: http://sedac.ciesin.columbia.edu/tg/ (accessed on 14 May 2009).

21. Welch, R. Monitoring Urban Population and Energy Utilization Patterns from Satellite Data. Remote Sens. Environ. 1980, 9, 1-9.

22. Welch R.; Zupko, S. Urban Area Energy Utilization Patterns from DMSP data. Photogrammetric Eng. Remote Sens. 1980, 46, 201-207.

23. Sutton, P.C.; Roberts, D.; Elvidge, C.D.; Baugh, K. Census from Heaven: An Estimate of Global Human Population Using Nighttime Satellite Imagery. Int. J. Remote Sens. 2001, 22, 3061-3076.

24. Lo, C.P. Urban Indicators of China from Radiance Calibrated Digital DMSP-OLS Nighttime Images. Ann. Assoc. Am. Geogr. 2002, 92, 225-240.

25. Sutton, P.C. Modeling Population Density with Nighttime Satellite Imagery and GIS. Comput. Environ. Urban Syst. 1997, 21, 227-244.

26. Sutton, P.C.; Elvidge, C.D.; Obremski, T. Building and Evaluating Models to Estimate Ambient Population Density. Photogrammetric Eng. Remote Sens. 2003, 69, 545-552.

27. Elvidge, C.D.; Baugh, K.E.; Kihn, E.A.; Koehl, H.W.; Davis, E.R.; Davis, C.W. Relation Between Satellite Observed Visible Near-infrared Emissions, Population, Economic Activity and Power Consumption. Int. J. Remote Sens. 1997, 18, 1373-1379.

28. Imhoff, M.L.; Lawrence, W.T.; Stutzer, D.C.; Elvidge, C.D. A Technique for Using Composite DMSP-OLS “City Lights" Satellite Data to Map Urban Area. Remote Sens. Environ. 1997, 61, 361-370.

29. Elvidge, C.D.; Tuttle, B.T.; Sutton, P.C.; Baugh, K.E.; Howard, A.T.; Milesi, C.; Bhaduri, B.; Nemani, R. Global Distribution and Density of Constructed Impervious Surfaces. Sensors 2007, 7, 1962-1979. 
30. Doll, C.N.H.; Muller, J.P.; Elvidge, C.D. Nighttime Imagery as a Tool for Global Mapping of Socioeconomic Parameters and Greenhouse Gas Emissions. Ambio 2000, 29, 157-162.

31. Doll, C.N.H. Estimating Non-population Activities from Nighttime Satellite Imagery, In Remotely Sensed Cities; Mesev, V. Ed.; Taylor and Francis: London and New York, 2003; pp. 335-353.

32. Sutton, P.C.; Costanza, R. Global Estimates of Market and Non-market Values Derived from Nighttime Satellite Imagery, Land Cover, and Ecosystem Service Evaluation. Ecol. Eco. 2002, 41, 509-527.

33. Sutton, P.C.; Cova, T.; Elvidge, C.D. Mapping "Exurbia" in the Conterminous United States Using Nighttime Satellite Imagery. Geocarto. Int. 2006, 21, 39-45.

34. Rodhouse, P.G.; Elvidge, C.D.; Trathan, P.N. Remote Sensing of the Global Lightfishing Fleet: An Analysis of Interactions with Oceanography, Other Fisheries and Predators. Adv. Marine Biol. 2001, 39, 261-303.

35. Cova, T.J.; Sutton, P.C.; Theobald, D.M. Exurban Change Detection in Fire-prone Areas with Nighttime Satellite Imagery. Photogrammetric Eng. Remote Sens. 2004, 70, 1249-1257.

36. Mattera, P. Off the books: The Rise of the Underground Economy; St. Martin's Press: New York, USA, 1985.

37. Perspective, “Going Underground”. Investor's Business Daily, December 21, 1998; Available online: http://www.ncpa.org/pd/economy/pd122198b.html (accessed on 25 January 2009).

38. Losby, J.L.; Else, J.F.; Kingslow, M.E.; Edgcomb, E.L.; Malm, E.T.; Kao, V. Informal Economy Literature Review, ISED Consulting and Research: Newark, and The Aspen Institute: Washington, DC, USA, 2002; Available online: http://www.ised.us/doc/Informal\%20Economy\%20Lit\%20 Review.pdf (accessed on 14 May 2009).

39. McTague, J. Going Underground: America's Shadow Economy, FrontPage Magazine, January 6, 2005; Available online: http://www.frontpagemag.com/readArticle.aspx?ARTID=10024 (accessed on 14 May 2009).

40. Elvidge, C.D.; Baugh, K.E.; Dietz, J.B.; Bland, T.; Sutton, P.C.; Kroehl, H.W. Radiance Calibration of DMSP-OLS Low-light Imaging Data of Human Settlements. Remote Sens. Environ. 1999, 68, 77-88.

41. LandScan Global Population Database. Oak Ridge National Laboratory: Oak Ridge, Tennessee, 2000; Available online: http://www.ornl.gov/landscan/ (accessed on 14 May 2009).

42. USA Census Bureau, USA Bureau of Economic Analysis, 2000; Available online: http://www.bea.gov/regional/gsp/ (accessed on 14 May 2009).

43. World Bank. World Development Report 2002: Building Institutions for Markets; Oxford University Press: New York, USA, 2002.

44. Population Reference Bureau. 2000 World Population Data Sheet - Demographic data and Estimates for the Countries and Regions of the World; Population Reference Bureau: Washington, DC, USA, 2000.

45. INEGI. Total de la actividad económica, 2000; Available online: http://dgcnesyp.inegi.gob.mx /CGI-WIN/BDIEINTSI.EXE/NIVM1500020001000100100005\# ARBOL (accessed on 14 May 2009).

46. World Bank. World Development Report 1994: Infrastructure for Development; Oxford University Press: New York, USA, $1994 b$. 
47. INEGI. Sistema de Cuentas Nacionales de México, Producto interno bruto, a precios de Mercado, 1999-2004; Available online: http://www.inegi.gob.mx/prod_serv/contenidos/espanol/ bvinegi/productos/derivada/cuentas/bienes\%20y\%20servicios/2004/cbys1999-2004.pdf (accessed on 14 May 2009).

48. Bureau of Economic Analysis, Washington, D.C., USA, Personal Communication, January 15, 2008.

49. Min, B. Democracy and Light: Electoral Accountability and the Provision of Public Goods. (Unpublished Manuscript).

50. INEGI. Sistema de Cuentas Nacionales de México, Cuentas por Sectores Insititucionales, Cuenta Satelite del Subsector informal de los hogares, 1998-2003; Available online: http://www.inegi.gob.mx/prod_serv/contenidos/espanol/bvinegi/productos/derivada/satelite/hogar es/Informal2003.pdf (accessed on 14 May 2009).

51. Bank of Mexico. Annual Report, 2004; Available online: http:/www.banxico.org.mx/documents /\%7BBBCDBF46-1EEA-DEBF-CCDC-F61F161812FA\%7D.pdf (accessed on 14 May 2009).

52. Nordbeck, S. The Law of Allometric Growth. Michigan Inter-University Community of Mathematical Geographers: University of Michigan, Ann Arbor, 1965.

53. Tobler, W. Satellite Confirmation of Settlement Size Coefficients, Area 1969, 1, 30-34.

54. Sutton, P.C. A Scale-adjusted Measure of "Urban sprawl" Using Nighttime Satellite Imagery. Remote Sens. Environ. 2003, 86, 353-369.

55. Schneider, F.; Enste, D. Shadow Economies: Size, Causes and Consequences. J. Econ. Lit. American Economic Association 2000, 38, 77-114.

56. Vuletin, G. Measuring the Informal Economy in Latin America and the Caribbean, IMF Working Paper 2008 08/102.

57. INEGI. Producto interno bruto por entidad federativa. Participación sectorial por entidad federative, 2000; Available from: http://www.inegi.org.mx/inegi/default.aspx (accessed on 14 May 2009).

58. Consejo Nacional de Población. Índices de Desarrollo Humano, 2000; Available from: http://www.conapo.gob.mx/publicaciones/desarrollo/001.pdf (accessed on 28 February 2009).

59. Elvidge, C.D.; Cinzano, P.; Pettit, D.R.; Aversen, J.; Sutton, P.C.; Small, C.; Nemani, R.; Longcore, T.; Rich, C.; Safran, J.; Weeks, J.; Ebener, S. The Nighsat mission concept. Int. J. Remote Sens. 2007, 28, 2645-2670.

(C) 2009 by the authors; licensee Molecular Diversity Preservation International, Basel, Switzerland. This article is an open-access article distributed under the terms and conditions of the Creative Commons Attribution license (http://creativecommons.org/licenses/by/3.0/). 